Supporting Information

\title{
Cyclohexeno[3,4]cyclodec-1,5-diyne-3-ene: A Convenient Enediyne
}

\author{
Annadka Shrinidhi and Charles L. Perrin* \\ Department of Chemistry \& Biochemistry, University of California-San Diego, La Jolla, \\ California 92093-0358, USA
}

*Corresponding author: cperrin@ucsd.edu

\section{Contents}

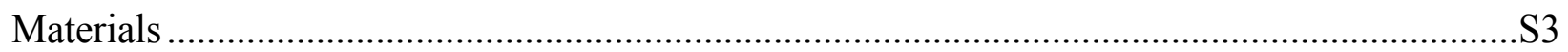

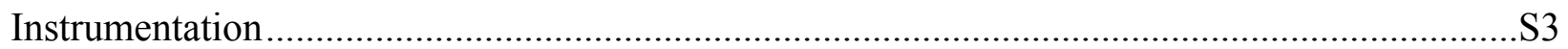

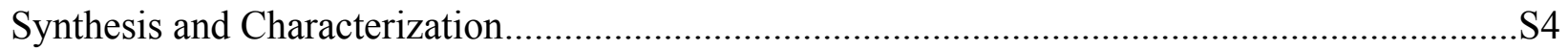

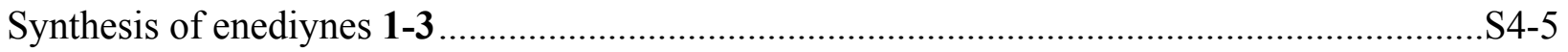

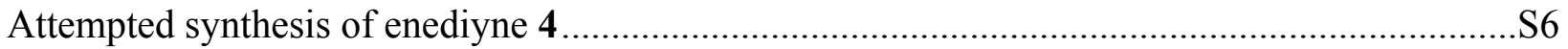

Reaction of enediyne 3 with nucleophiles: Synthesis of 9-X-octahydroanthracenes (5X).......S6-8

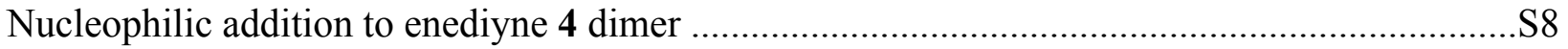

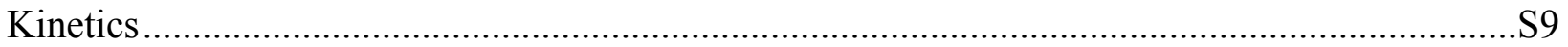

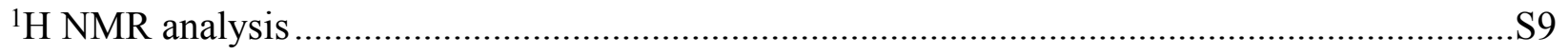

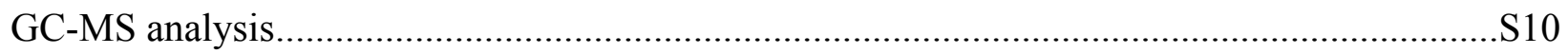

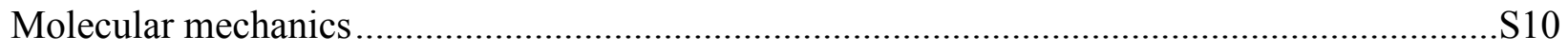

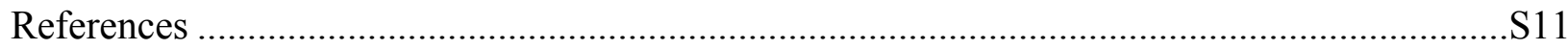

Figure S1-2. ${ }^{1} \mathrm{H},{ }^{13} \mathrm{C},{ }^{1} \mathrm{H}-{ }^{1} \mathrm{H}$ COSY NMR and HR-APCI-TOFMS spectra of cyclohexeno[3,4]-

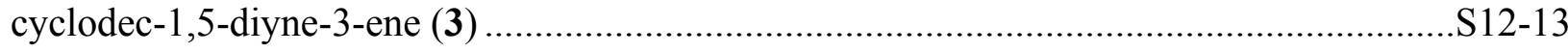

Figure S3-7. ${ }^{1} \mathrm{H}$ and ${ }^{13} \mathrm{C}$ NMR spectra of 9-X-1,2,3,4,5,6,7,8-octahydroanthracene (5X)....S14-18 
Figure S8. ${ }^{1} \mathrm{H}$ NMR spectra from experiment involving reaction of $5 \mathrm{mM}$ enediyne 3 in $50 \mathrm{mM}$ pivalic acid in DMSO- $d_{6}$ at $75^{\circ} \mathrm{C}$ at $0 \mathrm{~h} \mathrm{(1)}$ and at $20 \mathrm{~h} \mathrm{(2)} \mathrm{and,} \mathrm{with} \mathrm{nucleophiles} \mathrm{(100} \mathrm{equiv,} 500$

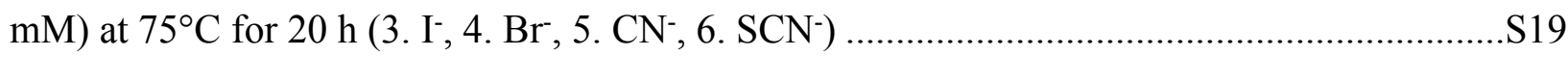
Figure S9. Typical ${ }^{1} \mathrm{H}$ NMR spectra from experiment involving $3(5 \mathrm{mM})$, LiI $(500 \mathrm{mM})$, and pivalic acid $(50 \mathrm{mM})$ in DMSO- $d_{6}$ at $75^{\circ} \mathrm{C}$. S20 Figure S10. Plot of $[3]_{\mathrm{t}} /[3]_{0}$ versus time for experiments involving enediyne $3(5 \mathrm{mM})$, nucleophile

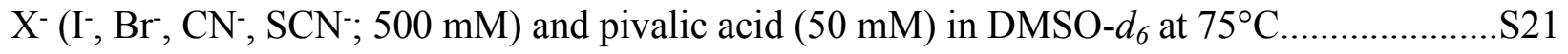

Figure S11. Plot of $\ln [3]_{\mathrm{t}} /[3]_{0}$ versus time for experiments involving enediyne $3(5 \mathrm{mM})$, nucleophile $\mathrm{X}^{-}(500 \mathrm{mM})$ and pivalic acid $(50 \mathrm{mM})$ in DMSO- $d_{6}$ at $75^{\circ} \mathrm{C}$ .S22

Table S1. First-order rate constants and free energies of activation for the disappearance of enediynes 1-3 $(5 \mathrm{mM})$ in the presence of LiX and pivalic acid $(7.5 \mathrm{mM})$ in DMSO- $d_{6} \ldots \ldots \ldots \ldots . . . \mathrm{S} 23$

Table S2. Distances $(\AA)$, bond angles $\left({ }^{\circ}\right)$, and total strain energies $(\mathrm{kcal} / \mathrm{mol})$ in MM2-energyminimized structures of enediynes 1-3 S24 


\section{Materials}

Common organic solvents and reagents were obtained from commercial suppliers and used as received without additional purification. Lithium iodide (99\%), tetrabutylammonium iodide (98\%), tetrabutylammonium bromide (98\%), tetrabutylammonium cyanide (98\%), tetrabutylammonium thiocyanate (98\%), tetrabutylammonium nitrite $(95 \%)$, bromine (98\%) and $n$-butyllithium (2.5 M in hexanes) were obtained from Aldrich Chemical, Inc. Cyclopentanone (99\%), cyclohexanone (99\%), sodium cyanide (98\%), potassium thiocyanate (98\%) and phosphorous pentachloride (98\%) were obtained from Fisher Scientific International, Inc. 1,4-

Dibromobutane (99\%), 1,4-diiodobutane (98\%), 1,2-diiodobenzene (98\%) and bis(triphenylphosphine)palladium(II) dichloride $\left(\mathrm{Pd}\left(\mathrm{Ph}_{3} \mathrm{P}\right)_{2} \mathrm{Cl}_{2}, 98 \%\right)$ were obtained from Oakwood Chemical, Inc. Trimethylsilylacetylene (98\%), sodium nitrite (98\%) and lithium bromide (98\%) were obtained from TCI Chemicals. Chloroform- $d\left(\mathrm{CDCl}_{3}, 99.9 \%\right.$ D) and dimethylsulfoxide- $d_{6}\left(\mathrm{DMSO}-d_{6}, 99.9 \% \mathrm{D}\right)$ were obtained from Cambridge Isotope Laboratories, Inc.

\section{Instrumentation}

${ }^{1} \mathrm{H}$ NMR spectra were obtained on either JEOL ECA 500MHz, Varian VX $500 \mathrm{MHz}$, Varian $\mathrm{Hg}+400 \mathrm{MHz}$, or Bruker AVA $300 \mathrm{MHz}$ spectrometer. ${ }^{13} \mathrm{C}$ NMR spectra were obtained on a Varian VX $500 \mathrm{MHz}$ FT-NMR spectrometer $\left(125.8 \mathrm{MHz}{ }^{13} \mathrm{C}\right)$, and ${ }^{1} \mathrm{H}-{ }^{1} \mathrm{H}$ COSY NMR spectra were obtained on a JEOL ECA500 FT-NMR spectrometer $\left(500.2 \mathrm{MHz}{ }^{1} \mathrm{H}\right)$. Tetramethylsilane (TMS, $0 \mathrm{ppm})$ or solvents $\left(\mathrm{CHCl}_{3} / \mathrm{CDCl}_{3}, \mathrm{DMSO} / \mathrm{DMSO}-d_{6}\right)$ were used as internal standards. Kinetic studies were done using Varian VX 500 MHz FT-NMR spectrometer $\left(500.2 \mathrm{MHz}{ }^{1} \mathrm{H}\right)$ in DMSO- $d_{6}$ with 1,3,5-trichlorobenzene (7.66 ppm) as internal standard. Spectra were processed using Bruker TopSpin 4.0 Academic Edition or MestReNova v12.0 software. GCEI-MS (electron ionization) was obtained on an Agilent 7820A gas chromatograph coupled with a 5977B MSD detector operated in scan mode from $10 \mathrm{~m} / \mathrm{z}$ to $400 \mathrm{~m} / \mathrm{z}$. HPLC-HR-ESI/APCI-MS (electrospray ionization, ESI, or atmospheric pressure chemical ionization source, APCI) was obtained on an Agilent 6230 Accurate-Mass TOFMS system using ESI/TOF-MS in a positive or negative-ion mode. 


\section{Synthesis and Characterization}

\section{Synthesis of enediynes 1-3}

Cyclodec-1,5-diyne-3-ene (1) was prepared by the cyclization of 1,10-dibromo-2,8octadiyne via carbenoid coupling-elimination according to the modified procedure, ${ }^{1}$ adapted from the reported literature. ${ }^{2}$

3,4-Benzocyclodeca-1,5-diyn-3-ene (2) was prepared by the cyclization of 1,2diethynylbenzene $(0.5 \mathrm{~g}, 4.0 \mathrm{mmol})$ with 1,4-diiobutane $(1.3 \mathrm{~g}, 4.0 \mathrm{mmol})$ according to the literature procedure. ${ }^{3}$ White solid $(0.33 \mathrm{~g}, 46 \%)$. Mp. $74-75^{\circ} \mathrm{C}\left(\right.$ lit. $\left.^{4} 73.0-74.5^{\circ} \mathrm{C}\right) .{ }^{1} \mathrm{H}$ NMR: $\left(300 \mathrm{MHz}, \mathrm{CDCl}_{3}\right) \delta 7.31(\mathrm{~m}, 2 \mathrm{H}), 7.19(\mathrm{~m}, 2 \mathrm{H}), 2.46(\mathrm{~m}, 4 \mathrm{H}), 1.97(\mathrm{~m}, 4 \mathrm{H}) \mathrm{ppm} .{ }^{13} \mathrm{C}$ NMR $(126$ $\mathrm{MHz}) \mathrm{CDCl}_{3}: \delta 129.6,128.2,127.4,100.1,82.4,28.7,21.6$ ppm. HPLC-APCI-MS 181.1012, calculated for $\mathrm{C}_{14} \mathrm{H}_{13}[\mathrm{M}]^{+}: 181.1012$.

Bicyclo[8.4.0]tetradeca-1,7-diyne-13-ene (3) (IUPAC name, also known as cyclohexeno[3,4]cyclodec-1,5-diyne-3-ene) was synthesized from 1,2-diethynylcyclohex-1-ene and 1,4-diiobutane (Scheme S1) using an adaptation of the synthesis of 3,4-benzocyclodeca-1,5diyn-3-ene (2). ${ }^{3}$ Precursor 1,2-diethynylcyclohex-1-ene was synthesized by the Sonogashira coupling of 1,2-dibromocyclohex-1-ene with trimethylsilylacetylene followed by deprotection of the trimethylsilyl group. ${ }^{5}$ 1,2-Dibromocyclohex-1-ene was obtained by the treatment of cyclohexanone with phosphorus pentachloride and sodium bicarbonate to form 1chlorocyclohexene, followed by addition of bromine and dehydrochlorination with potassium hydroxide. ${ }^{6}$

Typical procedure. $n$-Butyllithium (2.5M solution in hexanes, $3.2 \mathrm{~mL}, 8.1 \mathrm{mmol})$ was added to a solution of 1,2-diethynylcyclohexene $(0.5 \mathrm{~g}, 3.8 \mathrm{mmol})$ in $100 \mathrm{~mL}$ of $\mathrm{THF}$ at $-78^{\circ} \mathrm{C}$ under argon. An hour later, 1,4-diiodobutane (1.2 g, $3.9 \mathrm{mmol})$ was added dropwise at $-78^{\circ} \mathrm{C}$, and stirring was continued for ca. $72 \mathrm{~h}$ at room temperature. The reaction was quenched by the addition of a saturated aqueous $\mathrm{NH}_{4} \mathrm{Cl}$ solution, concentrated, and then diluted with ether and water. The organic layer was separated, washed with water and with brine, dried over $\mathrm{MgSO}_{4}$, and solvents were removed in vacuum. The residue was purified by flash column chromatography (silica gel, $100 \%$ hexanes) to give cyclohexeno[3,4]cyclodec-1,5-diyne-3-ene $(3,0.32 \mathrm{~g}, 45 \%)$ as an off-white solid. mp 105-106 ${ }^{\circ}$ C. ATR-FT-IR (neat) $\tilde{v}_{\max } 2921,2855,2834,2198,1556,1447 \mathrm{~cm}^{-1}$. ${ }^{1} \mathrm{H}$ NMR 
$\left(300 \mathrm{MHz}, \mathrm{CDCl}_{3}\right) \delta 2.36(\mathrm{~m}, 4 \mathrm{H}), 2.15(\mathrm{~m}, 4 \mathrm{H}), 1.90(\mathrm{~m}, 4 \mathrm{H}), 1.61$ (m, 4H) ppm. (500 MHz, DMSO-d $\left.{ }_{6}\right) \delta 2.27(\mathrm{~m}, 4 \mathrm{H}), 2.05(\mathrm{~m}, 4 \mathrm{H}), 1.78(\mathrm{~m}, 4 \mathrm{H}), 1.54(\mathrm{~m}, 4 \mathrm{H}) \mathrm{ppm} .{ }^{13} \mathrm{C} \mathrm{NMR}(126 \mathrm{MHz})$ $\mathrm{CDCl}_{3}: \delta 129.6,98.6,85.4,29.2,28.1,21.8,21.6$ ppm. DMSO- $d_{6}: \delta 128.8,98.9,85.3,28.7,27.4$, 21.3, 20.8 ppm. HPLC-APCI-MS 185.1327, calculated for $\mathrm{C}_{14} \mathrm{H}_{17}[\mathrm{M}+\mathrm{H}]^{+}: 185.1325$.

Enediyne 3 was isolated in $45 \%$ yield, close to the $48 \%$ yield of enediyne 2 obtained by Semmelhack and co-workers. ${ }^{3}$ Other major byproducts formed during the reaction were characterized as 1-ethynyl-2-(6-iodohex-1-yn-1-yl)cyclohexene (18\%) and 1,2-bis(6-iodohex-1yn-1-yl)cyclohex-1-ene (13\%), obtained by either mono- or di- ethynyl C-H substitution with only one end of 1,4-diiodobutane, and a cycloeicosane (3\%) containing alternating 1,2diethynylcyclohexene and butane units, obtained by dimerization of 1,2-diethynylcyclohexene and 1,4-diiobutane (Scheme S1).

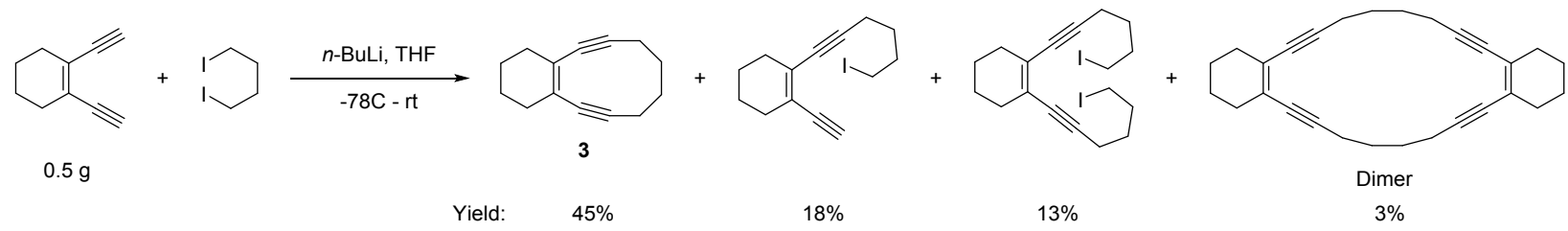

Scheme S1. Synthesis of cyclohexeno[3,4]cyclodec-1,5-diyne-3-ene (3)

The ${ }^{1} \mathrm{H}$ NMR spectrum of 3 in $\mathrm{CDCl}_{3}$ shows two multiplets at 2.36 and $2.15 \mathrm{ppm}$, typical of propargylic and allylic protons respectively, and two other multiplets at 1.90 and $1.61 \mathrm{ppm}$, corresponding to homopropargylic and homoallylic protons respectively (Fig. S1a). ${ }^{1} \mathrm{H}-{ }^{1} \mathrm{H}$ COSY spectroscopy shows two strong crosspeaks, one correlating propargylic and homopropargylic protons and the other correlating allylic and homoallylic protons (Fig. S2a). ${ }^{13} \mathrm{C}$ NMR (Fig. S1b) and mass spectrometry (Fig. S2b) further confirm the structure of $\mathbf{3}$. Enediyne $\mathbf{3}$ is an off-white solid that melts in a range $105-106^{\circ} \mathrm{C}$ but with $\sim 20-25 \%$ decomposition (confirmed by a ${ }^{1} \mathrm{H} \mathrm{NMR}$ spectrum after melting). It was found to be stable under ambient conditions for more than a month and can be stored in powder form at $-10^{\circ} \mathrm{C}$ for more than a year with no apparent decomposition. Enediyne $\mathbf{3}$ is readily soluble in most organic solvents but is sparingly soluble in dimethyl sulfoxide (to $\sim 250 \mathrm{mM}$ ) at $25^{\circ} \mathrm{C}$. 


\section{Attempted synthesis of cyclopenteno[3,4]cyclodec-1,5-diyne-3-ene (4)}

Similar to cyclohexeno[3,4]cyclodec-1,5-diyne-3-ene (3), cyclopenteno[3,4]cyclodec-1,5diyne-3-ene (4) is an alternative model enediyne. As a higher homologue of $\mathbf{1}$ and lower homologue of 3 similar reactivity towards nucleophiles in solution can be expected. However, attempts to synthesize 4 via cyclization of 1,2-diethynylcyclopentene with 1,4-diiobutane, according to Semmelhack's procedure, ${ }^{3}$ furnished $20 \%$ cyclopenteno[3,4]cyclodec-1,5-diyne-3ene dimer (6, mp 97-98 ${ }^{\circ} \mathrm{C} .{ }^{1} \mathrm{H}$ NMR $\left(300 \mathrm{MHz}, \mathrm{CDCl}_{3}\right) \delta 2.47(\mathrm{~m}, 16 \mathrm{H}), 1.88(\mathrm{~m}, 4 \mathrm{H}), 1.76(\mathrm{~s}$, $8 \mathrm{H})$ ppm. HPLC-APCI-MS 341.2264, calculated for $\mathrm{C}_{26} \mathrm{H}_{29}[\mathrm{M}+\mathrm{H}]^{+}$: 341.2264.) as a major product while only a trace amount of 4 was formed. A Chem3D analysis for C1-C6 distances of 1,2-diethynylcyclopentene, 1,2-diethynylcyclohexene, and 1,2-diethynylbenzene (which react with 1,4-diiodobutane to form 4,3 and 2 , respectively) were found to be 4.21, 3.86, and $3.96 \AA$ respectively, supporting the fact that a larger C1-C6 distance in 4 may lead to its dimerization with 1,4-diiodobutane rather than monomeric cyclization.

\section{Reaction of enediyne 3 with nucleophiles: Synthesis of 9-X-1,2,3,4,5,6,7,8-octahydro- anthracenes (5X)}

When enediyne 3 was heated for $20 \mathrm{~h}$ at $75^{\circ} \mathrm{C}$ in a DMSO solution containing a large excess of lithium iodide and pivalic acid, 9-iodo-1,2,3,4,5,6,7,8-octahydroanthracene (5I) was isolated in 93\% yield (Table 1). This behavior is similar to that of other enediynes 1 and 2 under such conditions. Therefore, we conclude that $\mathbf{3}$ undergoes electrocyclization to a 1,4-dehydrobenzene diradical that adds nucleophilic iodide ion, followed by protonation by acid or solvent. Table 1 also lists isolated yields $( \pm 5 \%)$ for the reaction of enediyne 3 with other nucleophiles. The isolated yields of products 9 -X-1,2,3,4,5,6,7,8-octahydroanthracene $\mathbf{( 5 X )}$ decrease with nucleophilicity (I$>\mathrm{SCN}^{-}>\mathrm{Br}^{-}>\mathrm{CN}^{-}>\mathrm{NO}_{2}^{-}$), but surprisingly, in the case of $\mathrm{SCN}^{-}$, the yield of $\mathbf{5 S C N}$ was lower not only than that of $\mathbf{5 I}$ but also than that of $\mathbf{5 C N}$ and $\mathbf{5 N O}_{2}$. Enediyne $\mathbf{3}$ that was not converted into 5X was not recovered but was found to decompose either to $1,2,3,4,5,6,7,8$ octahydroanthracene $\mathbf{5 H}$ ) or to unidentified oligomers or polymers. Diluting the reaction mixture 5-10-fold did not decrease the extent of decomposition. Also, reducing the concentration of 3 below $5 \mathrm{mM}$ or increasing the concentration of $\mathrm{X}^{-}$above $500 \mathrm{mM}$ did not change the yields by more than $3 \%$. In the absence of added nucleophile enediyne 3 at $75^{\circ} \mathrm{C}$ completely decomposed in $20 \mathrm{~h}$, where $40 \%$ was characterized as $\mathbf{5 H}$ and other products were not identified. Isolated yields 
of products $\mathbf{5 X}$ in solvents other than dimethyl sulfoxide, such as acetonitrile or binary mixtures of dimethyl sulfoxide, acetonitrile, or water, varied by only $\pm 5 \%$. Nor did the more organic-soluble tetrabutylammonium salts of those anionic nucleophiles affect the product yield of final product by $>5 \%$.

General procedure. In a 50-mL round-bottom flask enediyne 3 (20 mg, $\sim 0.11 \mathrm{mmol}, \sim 5$ $\mathrm{mM}), \operatorname{MX}(10.9 \mathrm{mmol}, \sim 500 \mathrm{mM})$, and pivalic acid (110 mg, 1.0 mmol, $\sim 50 \mathrm{mM})$ in dimethyl sulfoxide $(22 \mathrm{~mL})$ were added and stirred at $75^{\circ} \mathrm{C}$ in an oil bath for $20 \mathrm{~h}$. The reaction mixture was added to saturated aqueous $\mathrm{NH}_{4} \mathrm{Cl}(100 \mathrm{~mL})$, followed by extraction with 3 x $10 \mathrm{~mL}$ of diethyl ether. The organic layer was washed with 3 × $20 \mathrm{~mL}$ of $\mathrm{H}_{2} \mathrm{O}$, dried over anhydrous $\mathrm{Na}_{2} \mathrm{SO}_{4}$, and concentrated in vacuo. The resulting crude products were purified by flash column chromatography (silica gel, 100\% hexanes).

9-Iodo-1,2,3,4,5,6,7,8-octahydroanthracene (5I).

It was synthesized from $3(20.0 \mathrm{mg}, 0.11 \mathrm{mmol})$ and LiI $(1.5 \mathrm{~g}, 10.9 \mathrm{mmol})$ and was purified by flash column chromatography (silica gel, 100\% hexanes) to yield the title compound (32 mg, 93\%). Pale yellow oil. ${ }^{1} \mathrm{H}$ NMR (300 MHz, $\left.\mathrm{CDCl}_{3}\right) \delta 6.81$ (s, 1H), 2.70 (m, 8H), 1.76 (ddt, $J=31.3,11.2,6.0 \mathrm{~Hz}, 8 \mathrm{H})$ ppm. ${ }^{13} \mathrm{C} \mathrm{NMR}\left(126 \mathrm{MHz}, \mathrm{CDCl}_{3}\right) \delta 137.5,136.3,130.2,113.2$, 37.3, 30.3, 24.6, 23.0 ppm; GC-EI-MS 312.0, calculated for $\mathrm{C}_{14} \mathrm{H}_{17} \mathrm{I}[\mathrm{M}]^{+}: 312.0$.

9-Bromo-1,2,3,4,5,6,7,8-octahydroanthracene (5Br).

It was synthesized from $3(20.0 \mathrm{mg}, 0.11 \mathrm{mmol})$ and $\mathrm{LiBr}(0.9 \mathrm{~g}, 10.9 \mathrm{mmol})$ and was purified by flash column chromatography (silica gel, 100\% hexanes) to yield the title compound (23 mg, 80\%). Pale yellow oil. ${ }^{1} \mathrm{H}$ NMR (500 MHz, $\left.\mathrm{CDCl}_{3}\right) \delta 6.79$ (s, 1H), 2.74-2.70 (m, 8H), 1.84-1.77 (m, 4H), 1.74-1.69 (m, 4H) ppm. ${ }^{13} \mathrm{C}$ NMR (126 MHz, $\left.\mathrm{CDCl}_{3}\right) \delta 136.3,134.2,129.4$, 128.9, 30.9, 29.9, 23.8, 22.9 ppm; GC-EI-MS 265.2, calculated for $\mathrm{C}_{14} \mathrm{H}_{17} \mathrm{Br}[\mathrm{M}]^{+}: 265.2$.

\section{1,2,3,4,5,6,7,8-Octahydroanthracene-9-carbonitrile $(\mathbf{5 C N})$.}

It was synthesized from $3(20.0 \mathrm{mg}, 0.11 \mathrm{mmol})$ and $\mathrm{NaCN}(0.5 \mathrm{~g}, 10.9 \mathrm{mmol})$ and was purified by flash column chromatography (silica gel, 100\% hexanes) to yield the title compound (17 mg, 75\%). Pale yellow oil. ${ }^{1} \mathrm{H}$ NMR (500 MHz, $\left.\mathrm{CDCl}_{3}\right) \delta 6.98(\mathrm{~s}, 1 \mathrm{H}), 2.89$ (t, $J=6.3 \mathrm{~Hz}$, $4 \mathrm{H}), 2.69(\mathrm{t}, J=6.2 \mathrm{~Hz}, 4 \mathrm{H}), 1.80(\mathrm{dh}, J=23.5,6.2 \mathrm{~Hz}, 8 \mathrm{H}) \mathrm{ppm} .{ }^{13} \mathrm{C} \mathrm{NMR}\left(126 \mathrm{MHz}, \mathrm{CDCl}_{3}\right) \delta$ 
138.6, 135.2, 134.2, 117.4, 112.8, 29.1, 28.1, 22.8, 22.8 ppm; GC-EI-MS 211.1, calculated for $\mathrm{C}_{15} \mathrm{H}_{17} \mathrm{~N}[\mathrm{M}]^{+}: 211.1$.

9-Thiocyanato-1,2,3,4,5,6,7,8-octahydroanthracene (5SCN).

It was synthesized from $3(20.0 \mathrm{mg}, 0.11 \mathrm{mmol})$ and KSCN $(1.0 \mathrm{~g}, 10.9 \mathrm{mmol})$ and was purified by flash column chromatography (silica gel, 100\% hexanes) to yield the title compound (17 mg, 63\%). Pale yellow oil. ${ }^{1} \mathrm{H}$ NMR (500 MHz, $\left.\mathrm{CDCl}_{3}\right) \delta 6.96(\mathrm{~s}, 1 \mathrm{H}), 2.98(\mathrm{t}, J=6.4 \mathrm{~Hz}$, 4H), $2.72(\mathrm{t}, J=6.3 \mathrm{~Hz}, 4 \mathrm{H}), 1.85(\mathrm{dt}, J=12.1,6.2 \mathrm{~Hz}, 4 \mathrm{H}), 1.75(\mathrm{dt}, J=11.9,6.0 \mathrm{~Hz}, 4 \mathrm{H}) \mathrm{ppm}$. ${ }^{13} \mathrm{C} \mathrm{NMR}\left(126 \mathrm{MHz}, \mathrm{CDCl}_{3}\right) \delta 139.0,136.8,133.5,122.8,111.3,29.8,29.1,23.5,22.6$ ppm; GCEI-MS 243.1, calculated for $\mathrm{C}_{15} \mathrm{H}_{17} \mathrm{NS}[\mathrm{M}]^{+}: 243.1$.

9-Nitro-1,2,3,4,5,6,7,8-octahydroanthracene $\left(\mathbf{5 N O}_{\mathbf{2}}\right)$.

It was synthesized from $3(20.0 \mathrm{mg}, 0.11 \mathrm{mmol})$ and $\mathrm{NaNO}_{2}(0.8 \mathrm{~g}, 10.9 \mathrm{mmol})$ and was purified by flash column chromatography (silica gel, 100\% hexanes) to yield the title compound (9 mg, 36\%). Pale yellow oil. ${ }^{1} \mathrm{H}$ NMR (500 MHz, $\left.\mathrm{CDCl}_{3}\right) \delta 6.91(\mathrm{~s}, 1 \mathrm{H}), 2.73(\mathrm{t}, J=5.3 \mathrm{~Hz}, 4 \mathrm{H})$, $2.60(\mathrm{t}, J=5.3 \mathrm{~Hz}, 4 \mathrm{H}), 1.77(\mathrm{dt}, J=6.5,3.0 \mathrm{~Hz}, 8 \mathrm{H}) \mathrm{ppm} .{ }^{13} \mathrm{C} \mathrm{NMR}\left(126 \mathrm{MHz}, \mathrm{CDCl}_{3}\right) \delta 136.1$, 131.4, 125.2, 124.0, 29.9, 29.2, 24.0, 22.5 ppm; GC-EI-MS 231.1, calculated for $\mathrm{C}_{14} \mathrm{H}_{17} \mathrm{NO}_{2}[\mathrm{M}]^{+}$: 231.1 .

\section{Nucleophilic addition to enediyne 4 dimer}

Attempted reaction of cyclopenteno[3,4]cyclodec-1,5-diyne-3-ene dimer (6) with $\mathrm{X}^{-}\left(\mathrm{I}^{-}\right.$, $\mathrm{Br}^{-}, \mathrm{CN}^{-}, \mathrm{SCN}^{-}, \mathrm{N}_{3}^{-}, \mathrm{NO}_{2}^{-}$, etc.) furnished no 4,9-di-X-1,2,3,5,6,7,8,10,11,12,14,15,16,17tetradecahydrocyclododeca[1,2-f:7,8-f']diindene (7) even after heating at $105^{\circ} \mathrm{C}$ in an oil bath for 24 h. Instead 6 was thermally stable and did not form decomposition products (Scheme S3). According to Chem3D, the C1-C6 distance in 6 is $4.11 \AA$, too large to form a 1,4-dehydrobenzene diradical, which supports its unreactivity toward nucleophiles.
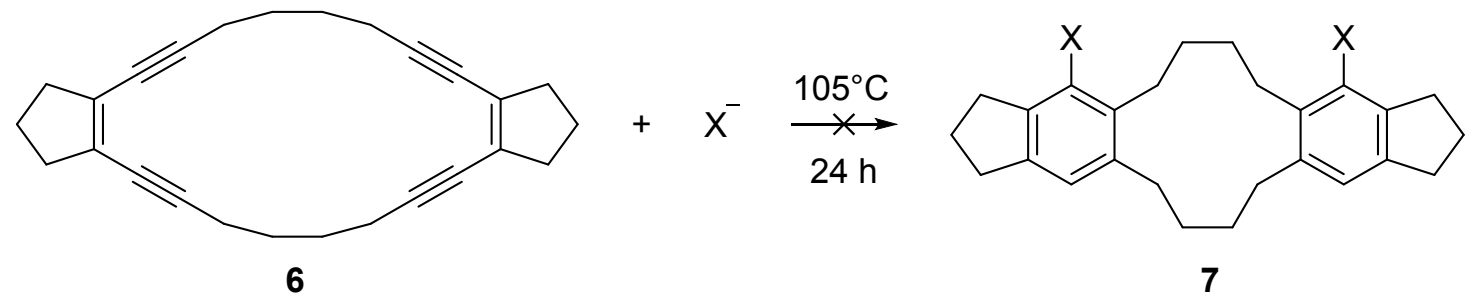
Scheme S3. Possible cycloaromatization of cyclopenteno[3,4]cyclodec-1,5-diyne-3-ene dimer (6) and addition of $\mathrm{X}^{-}$to form 4,9-di-X-1,2,3,5,6,7,8,10,11,12,14,15,16,17tetradecahydrocyclododeca[1,2-f: 7,8-f']diindene (7).

\section{Kinetics}

Enediyne $(1-3,5 \mathrm{mM})$ was added to a solution of nucleophile $\mathrm{X}^{-}(250-500 \mathrm{mM})$ and pivalic acid $(7.5 \mathrm{mM})$ in DMSO- $d_{6}(0.5 \mathrm{~mL})$ in an NMR tube containing 1,3,5-trichlorobenzene $(5 \mathrm{mM})$ as internal standard. The sample was degassed, sealed, and immersed in an oil bath at $45^{\circ} \mathrm{C}$ or $55^{\circ} \mathrm{C}$ for $1,85^{\circ} \mathrm{C}$ or $95^{\circ} \mathrm{C}$ for 2 , and $65^{\circ} \mathrm{C}$ or $75^{\circ} \mathrm{C}$ for 3 . Excess nucleophile and a low concentration of enediyne were used in order to minimize polymerization. Disappearance of starting material was monitored every $1.0 \mathrm{~h}$ by removing the sample and analyzing it by ${ }^{1} \mathrm{H}$ NMR. All studies were done in pairs or triplicates that differed in only one variable. Besides an initial ${ }^{1} \mathrm{H}$ NMR spectrum each sample was analyzed at intervals, until $\leq 2 \%$ of starting material remained. The time to remove the sample and acquire each spectrum was 10-20 min, which was subtracted from the time elapsed. The first-order rate constant $k$ was obtained from least-squares fitting to a logarithmic plot of [enediyne] versus time (Eq. 1). Nonlinear fitting to exponential decay gave nearly the same values. Rate constants $k$ and free energies of activation $\left(\Delta G^{\star}\right)$ for the disappearance of enediynes 1-3 in the presence of LiI and pivalic acid in DMSO- $d_{6}$ are given in Table S2.

$$
\ln \left([\mathbf{1 - 3}]_{t}\right)=-k t+\ln \left([\mathbf{1 - 3}]_{0}\right)
$$

For enediyne 2 plus 1,4-cyclohexadiene (1,4-CHD) the procedure was adapted from the reported literature. ${ }^{3}$ A solution of enediyne $2(5 \mathrm{mM})$ and 1,4-CHD $(250-500 \mathrm{mM})$ in $t$-BuOH $(25$ $\mathrm{mL})$ containing an aliquot of 1,3,5-trichlorobenzene $(5 \mathrm{mM})$ as internal standard was refluxed at $84^{\circ} \mathrm{C}$. About $0.5 \mathrm{~mL}$ of the reaction mixture was removed at specific intervals, evaporated to dryness, re-dissolved in DMSO- $d_{6}(0.5 \mathrm{~mL})$, and analyzed by ${ }^{1} \mathrm{H}$ NMR for the disappearance of 2 . Our results from kinetic studies with 1,4-CHD agree with those of Semmelhack. ${ }^{3}$

\section{${ }^{1} \mathrm{H}$ NMR analysis}

The absolute amount of remaining enediyne and yields of products were evaluated from the NMR integrations of corresponding signals, relative to internal standard and normalized to the initial spectrum. Disappearance of enediyne was monitored by comparing the integrated intensity of the olefinic $\mathrm{CH}$ for $\mathbf{1}(\delta 5.81 \mathrm{ppm}, \mathrm{s}, 2 \mathrm{H})$, the phenyl $\mathrm{CH}$ for $\mathbf{2}(\delta 7.28 \mathrm{ppm}, \mathrm{m}, 2 \mathrm{H})$, or the 
propargyl $\mathrm{CH}_{2}$ for $3(\delta 2.05 \mathrm{ppm}, \mathrm{m}, 4 \mathrm{H})$ to that of 1,3,5-trichlorobenzene $(\delta 7.66 \mathrm{ppm}, \mathrm{s}, 3 \mathrm{H})$. Formation of products for the reaction of 2 with nucleophiles $\mathrm{X}^{-}\left(=\mathrm{I}^{-}, \mathrm{Br}^{-}, \mathrm{CN}^{-}\right.$, and $\left.\mathrm{SCN}^{-}\right)$was monitored by the integrated intensity of ortho benzylic $\mathrm{CH}_{2}$ in $9-\mathrm{X}-1,2,3,4,5,6,7,8$ octahydroanthracene $(\delta 2.5-2.9 \mathrm{ppm})$. Owing to errors in integration, the accuracy of yields measured by ${ }^{1} \mathrm{H}$ NMR is generally $\pm 5 \%$.

\section{GC-MS analysis}

After NMR analysis, $\sim 0.1 \mathrm{~mL}$ of the solution was diluted to $1 \mathrm{~mL}$ with acetone and filtered through a $0.22-\mu \mathrm{m}$ syringe filter and injected into the GC. Products were distinguished by their intense signals in the FID-GC and the yield was determined using an empirical calibration curve.

\section{Molecular mechanics}

All molecular-mechanics calculations were performed using Chem3D (level: Ultra, version: 16.0.1.4) with the MM2 force field. The structures of enediynes (1-3) were minimized to a derivative RMS of $<0.01 \mathrm{~kJ} / \mathrm{A}$ and the global minimum structure was obtained after 10000 iterations. MM2 energy-minimized structures of enediynes 1-3 and measured parameters are listed in Table S2. 


\section{References}

(1) Reyes-Rodríguez, G. J. Nucleophilic Additions to a para-Benzyne Derived from an Enediyne : Exploring the Non-Radical Reactivity of a Diradical; University of California: San Diego, 2013; p 89-90.

(2) Jones, G. B.; Wright, J. M.; Plourde, G. W.; Hynd, G.; Huber, R. S.; Mathews, J. E. A Direct and Stereocontrolled Route to Conjugated Enediynes. J. Am. Chem. Soc. 2000, 122, 1937-1944.

(3) Semmelhack, M. F.; Neu, T.; Foubelo, F. Arene 1,4-Diradical Formation from $o$ Dialkynylarenes. J. Org. Chem. 1994, 59, 5038-5047.

(4) Darby, N.; Kim, C. U.; Salaün, J. A.; Shelton, K. W.; Takada, S.; Masamune, S. Concerning the 1,5-Didehydro[10]annulene System. J. Chem. Soc. D 1971, 1516-1517.

(5) Ashe, A. J.; Drone, F. J. 1-Methyl-4,5-cyclopentenoborepin: A Neutral Boron Analog of Tropylium. J. Am. Chem. Soc. 1987, 109, 1879-1880.

(6) Faworsky, A. L.; Boshowsky, W. Zur Frage Nach der Existenzfähigkeit Cyclischer Kohlenwasserstoffe mit Einer Dreifachen Bindung im Ring. Justus Liebigs Ann. Chem. 1912, 390, 122-129. 
(a)

${ }^{1} \mathrm{H}$ NMR (300 MHz, $\mathrm{CDCl}_{3}$ )

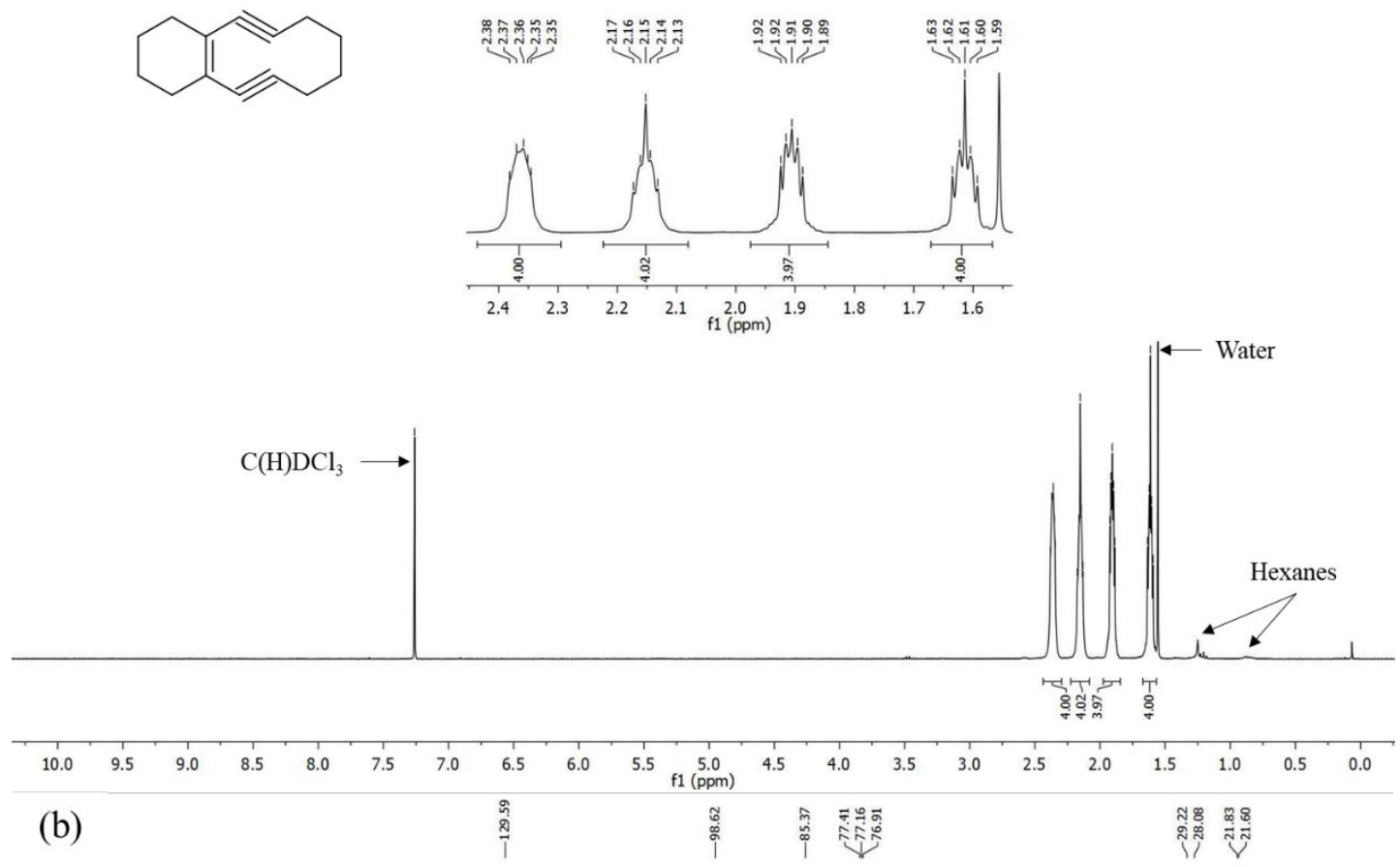

${ }^{13} \mathrm{C}$ NMR (126 MHz, $\mathrm{CDCl}_{3}$ )<smiles>C1#CC2=C(C#CCCCC2)CCCC1</smiles>

$\mathrm{C}(\mathrm{H}) \mathrm{DCl}_{3} \longrightarrow$

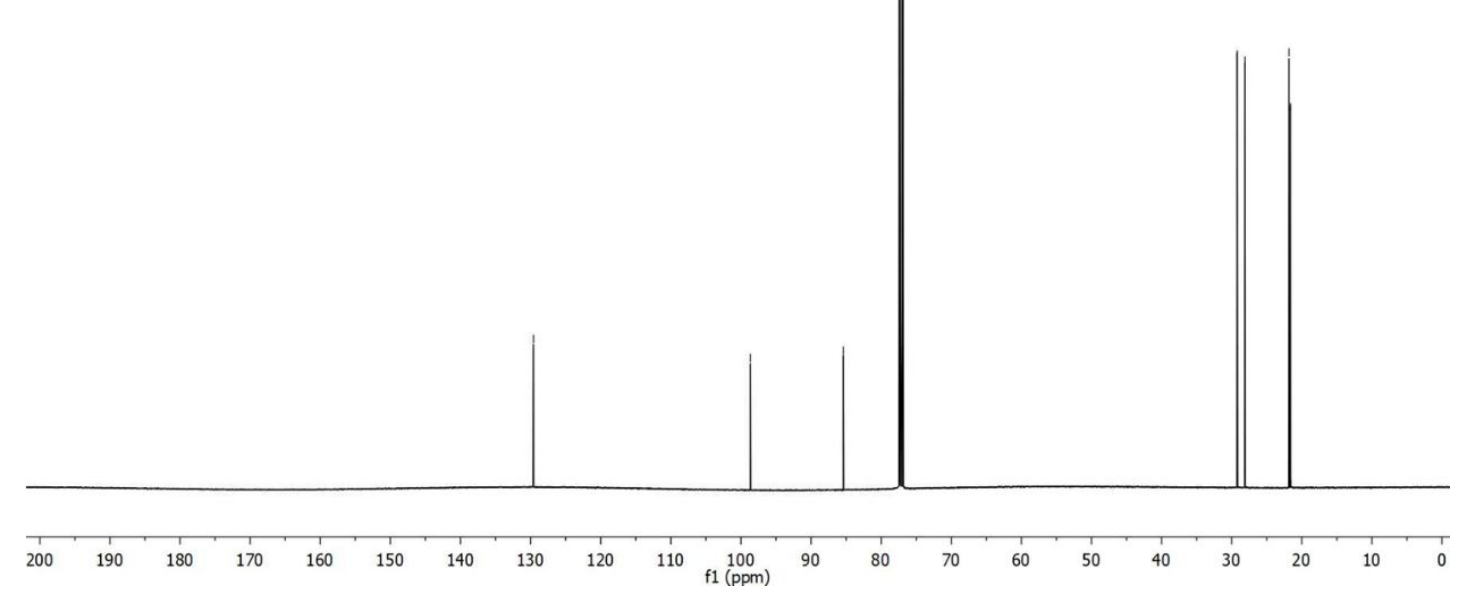

Figure S1. ${ }^{1} \mathrm{H}$ and ${ }^{13} \mathrm{C}$ NMR spectra of cyclohexeno[3,4]-cyclodec-1,5-diyne-3-ene (3) acquired in $\mathrm{CDCl}_{3}$. 

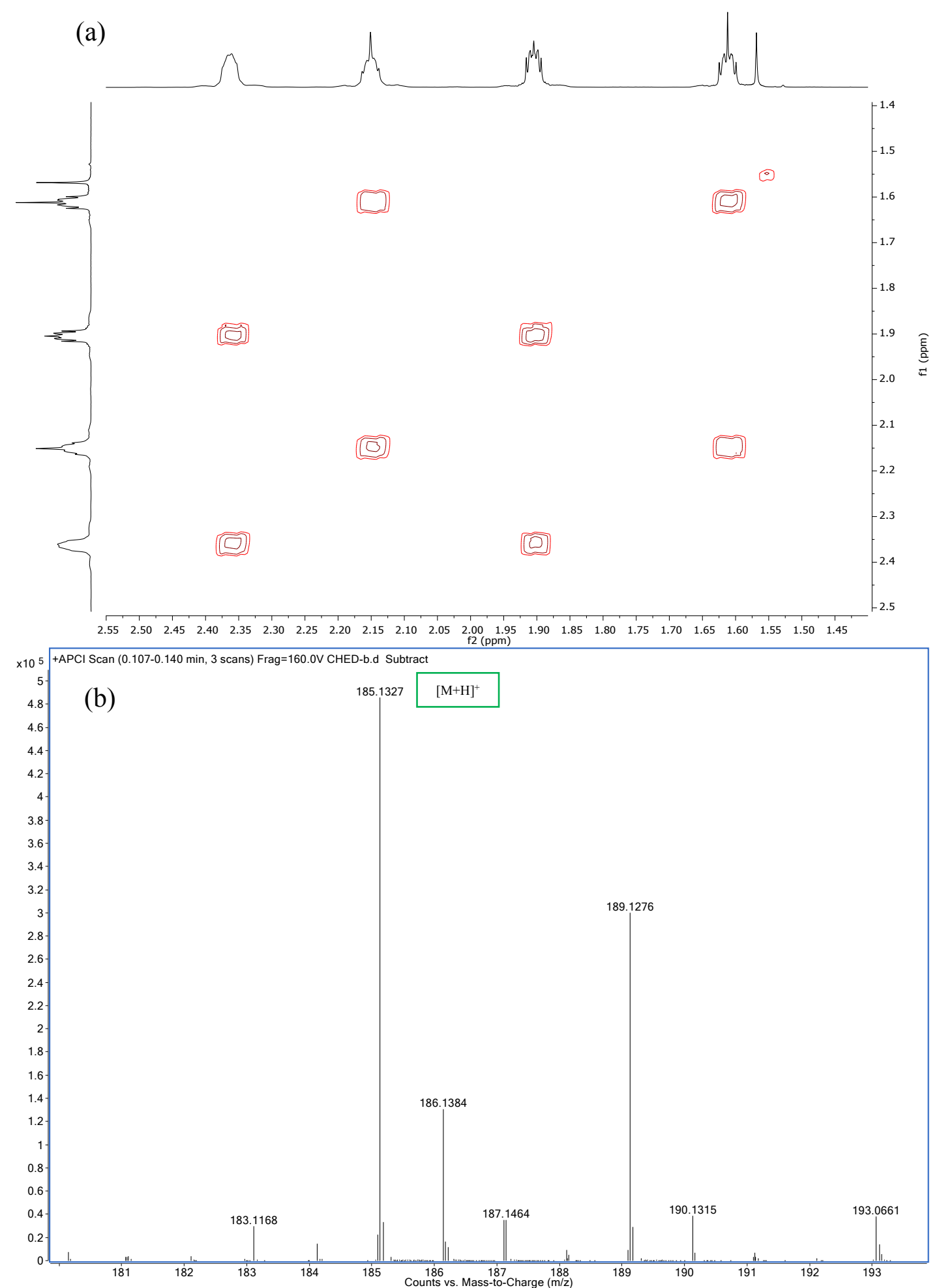

Figure S2. (a) ${ }^{1} \mathrm{H}-{ }^{1} \mathrm{H}$ COSY NMR spectrum in $\mathrm{CDCl}_{3}$ and (b) HR-APCI-TOFMS spectrum in positive ion mode of cyclohexeno[3,4]-cyclodec-1,5-diyne-3-ene (3). 
${ }^{1} \mathrm{H} \mathrm{NMR}\left(500 \mathrm{MHz}, \mathrm{CDCl}_{3}\right.$ )<smiles>Ic1c2c(cc3c1CCCC3)CCCC2</smiles>

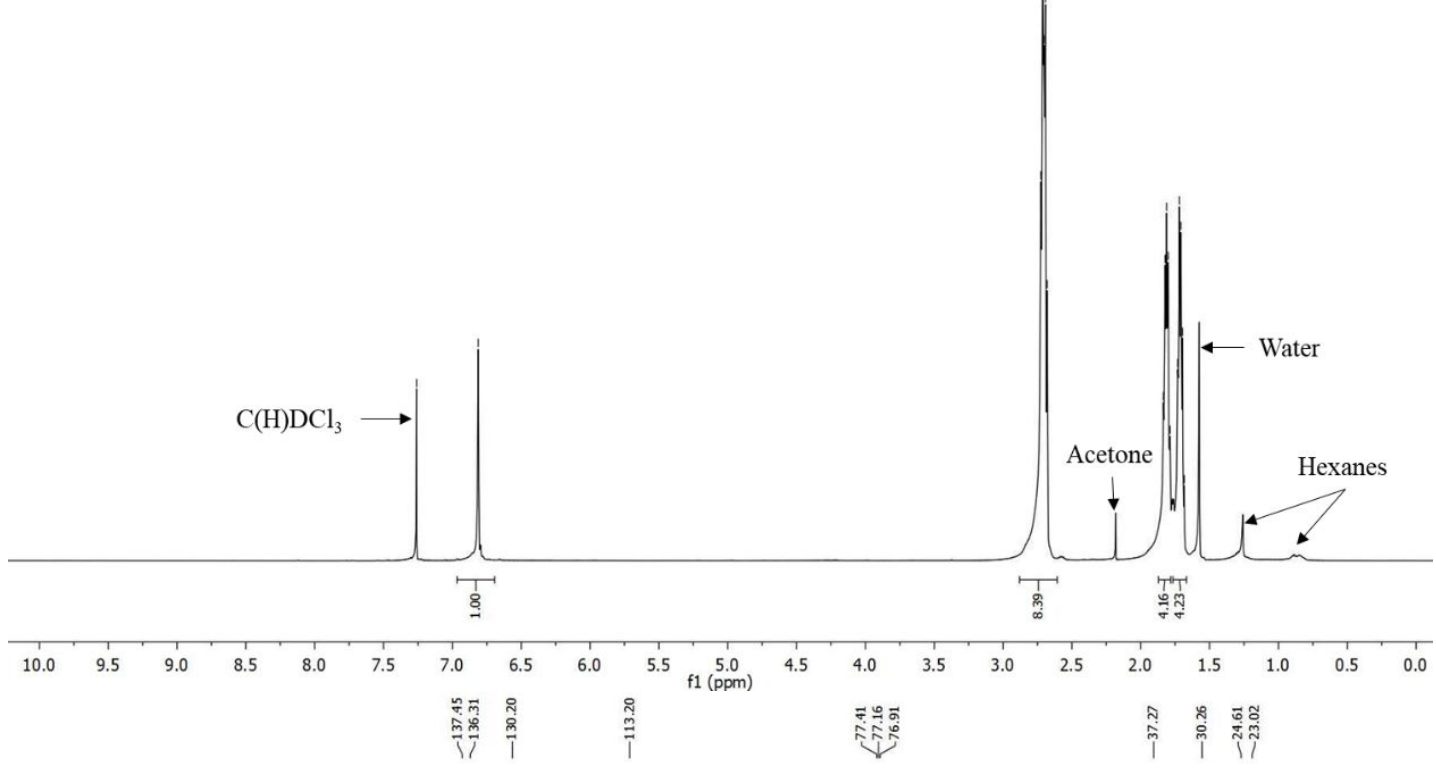

${ }^{13} \mathrm{C}$ NMR (126 MHz, $\left.\mathrm{CDCl}_{3}\right)$<smiles>Ic1c2c(cc3c1CCCC3)CCCC2</smiles>

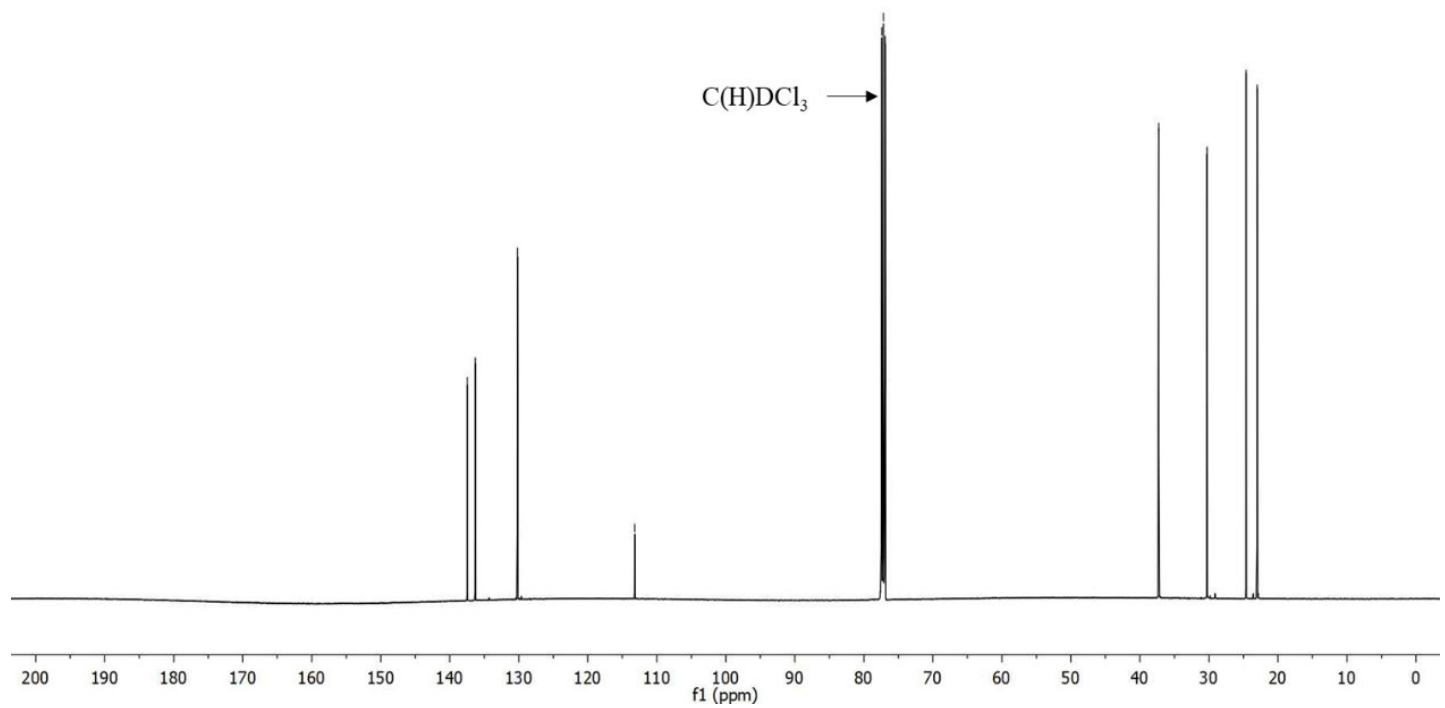

Figure $\mathrm{S} 3 .{ }^{1} \mathrm{H}$ and ${ }^{13} \mathrm{C}$ NMR spectra of 9-iodo-1,2,3,4,5,6,7,8-octahydroanthracene (5I) in $\mathrm{CDCl}_{3}$. 


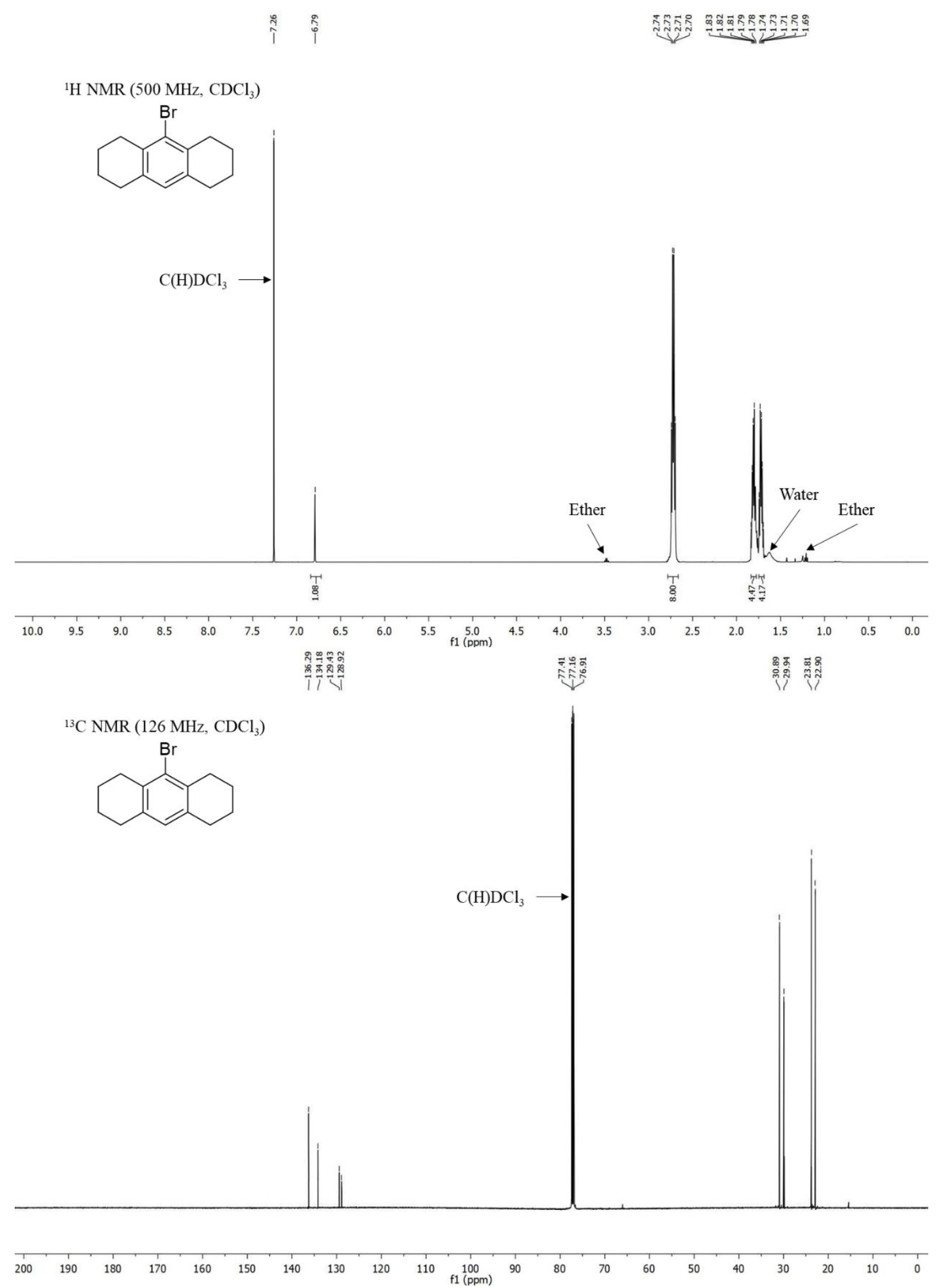

Figure S4. ${ }^{1} \mathrm{H}$ and ${ }^{13} \mathrm{C}$ NMR spectra of 9-bromo-1,2,3,4,5,6,7,8-octahydroanthracene (5Br) in $\mathrm{CDCl}_{3}$. 
${ }^{1} \mathrm{H}$ NMR $\left(500 \mathrm{MHz}, \mathrm{CDCl}_{3}\right)$<smiles>N#Cc1c2c(cc3c1CCCC3)CCCC2</smiles>

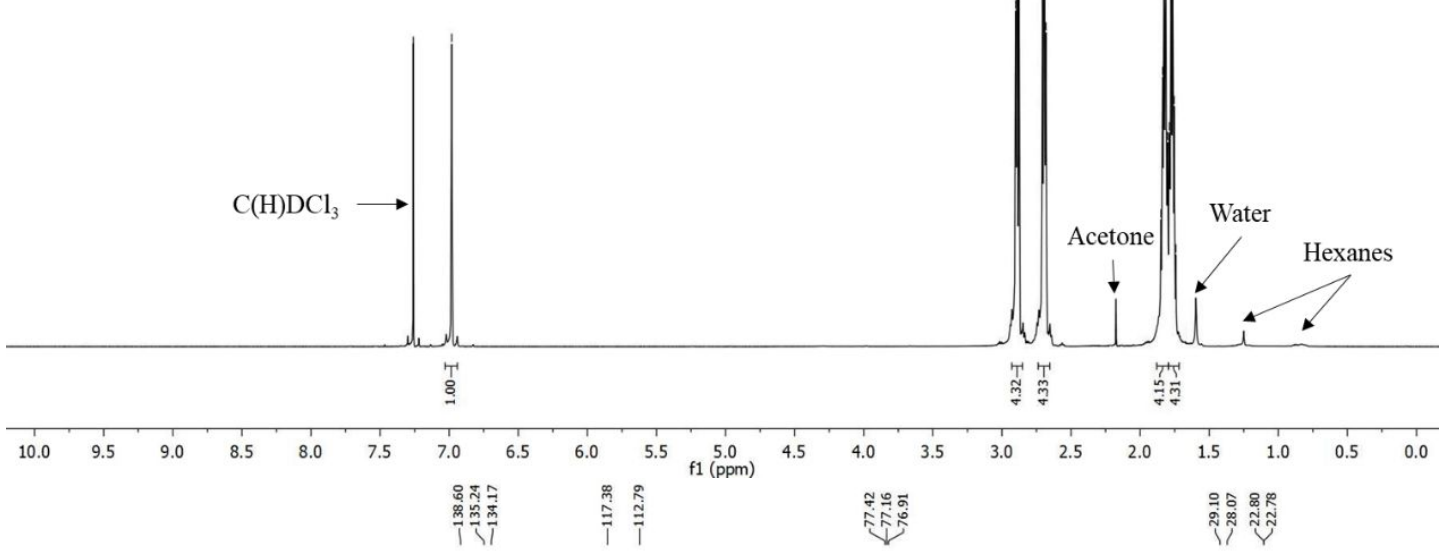

${ }^{13} \mathrm{C}$ NMR $\left(126 \mathrm{MHz}, \mathrm{CDCl}_{3}\right)$<smiles>N#Cc1c2c(cc3c1CCCC3)CCCC2</smiles>

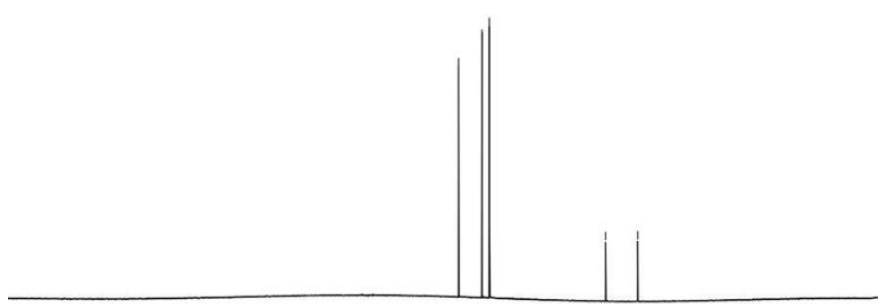

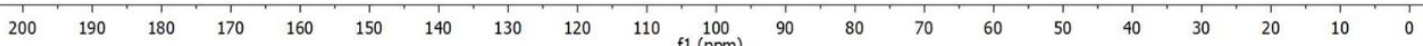

Figure S5. ${ }^{1} \mathrm{H}$ and ${ }^{13} \mathrm{C}$ NMR spectra of 1,2,3,4,5,6,7,8-octahydroanthracene-9-carbonitrile (5CN) in $\mathrm{CDCl}_{3}$. 


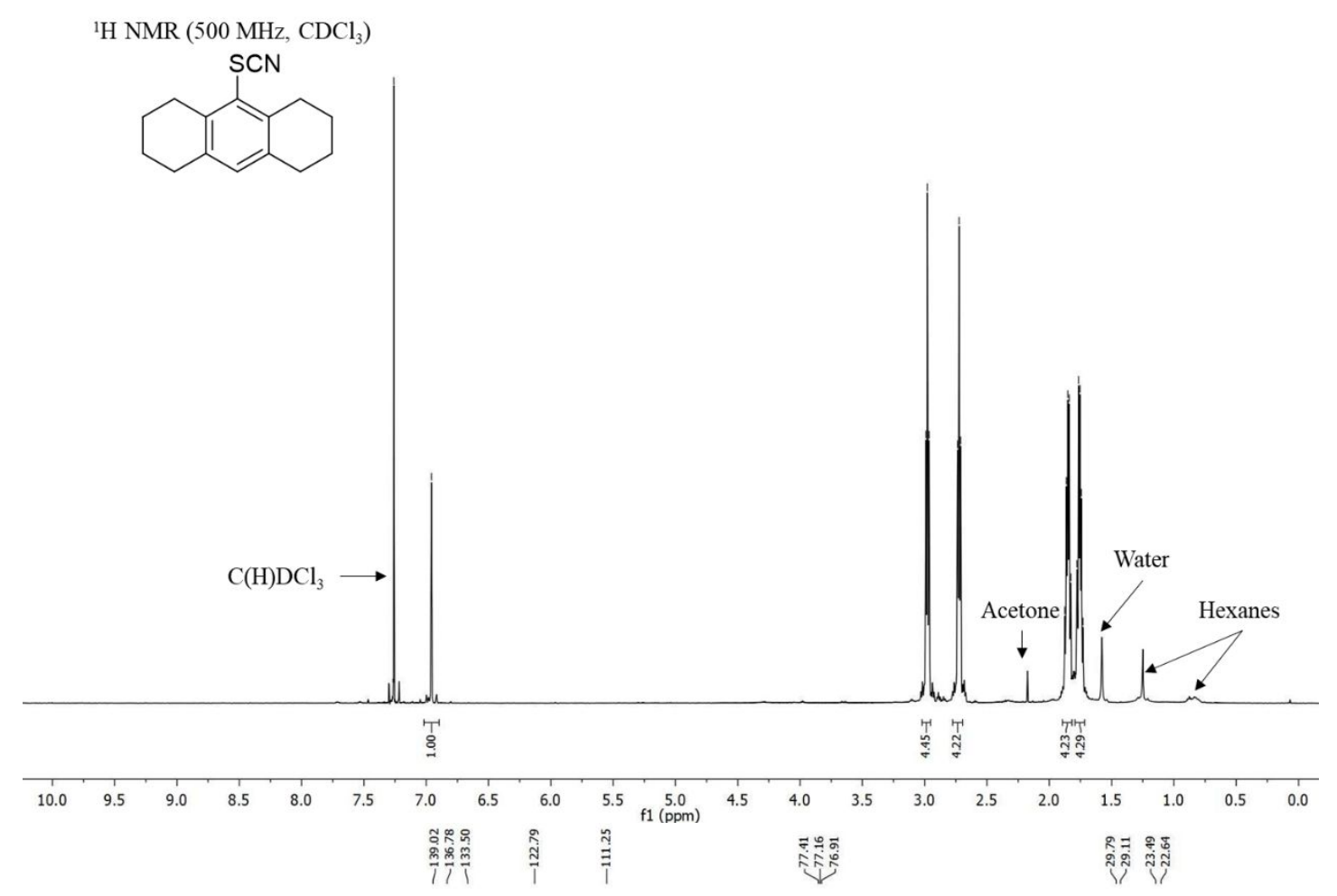

${ }^{13} \mathrm{C} \mathrm{NMR}\left(126 \mathrm{MHz}, \mathrm{CDCl}_{3}\right)$<smiles>N#Cc1c2c(cc3c1CCCC3)CCCC2</smiles>

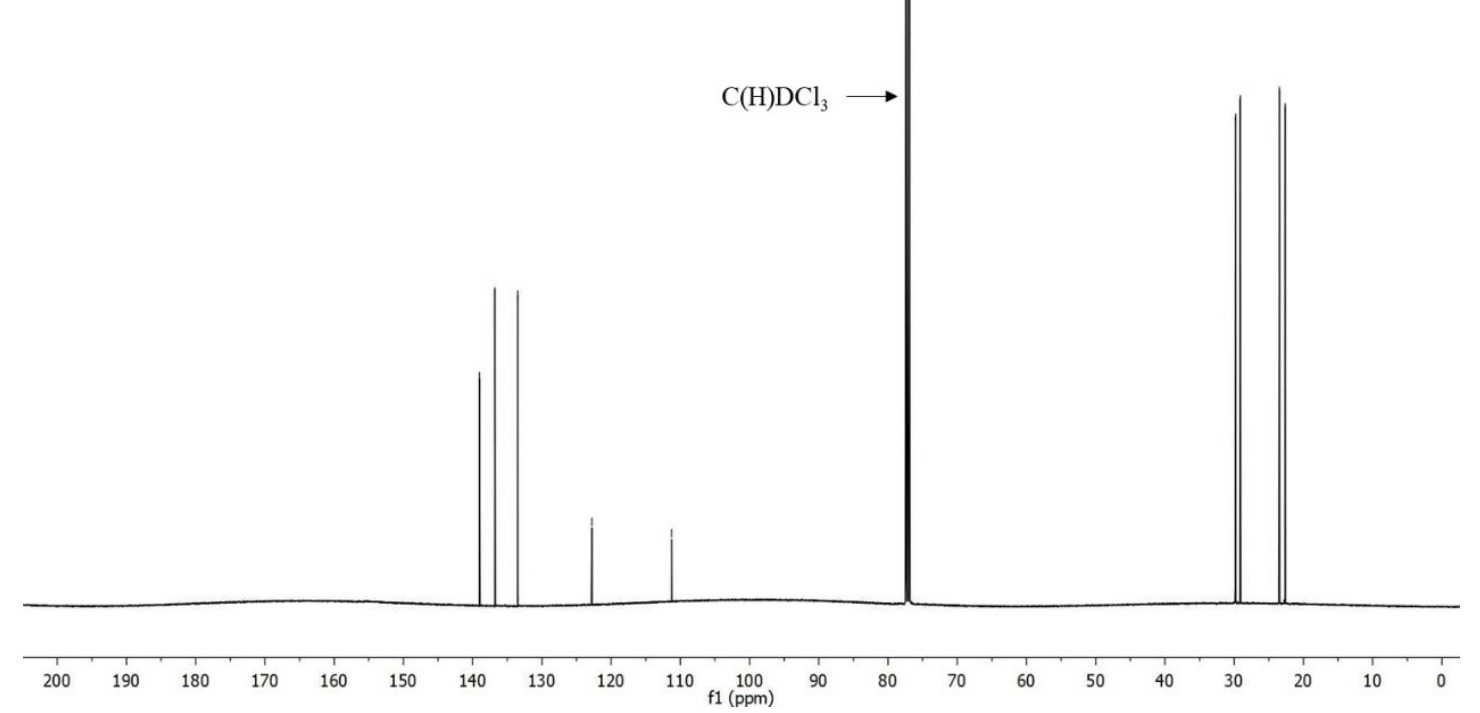

Figure S6. ${ }^{1} \mathrm{H}$ and ${ }^{13} \mathrm{C}$ NMR spectra of 9-thiocyanato-1,2,3,4,5,6,7,8-octahydroanthracene (5SCN) in $\mathrm{CDCl}_{3}$. 
${ }^{1} \mathrm{H}$ NMR (500 MHz, $\mathrm{CDCl}_{3}$ )<smiles>O=[N+]([O-])c1c2c(cc3c1CCCC3)CCCC2</smiles>

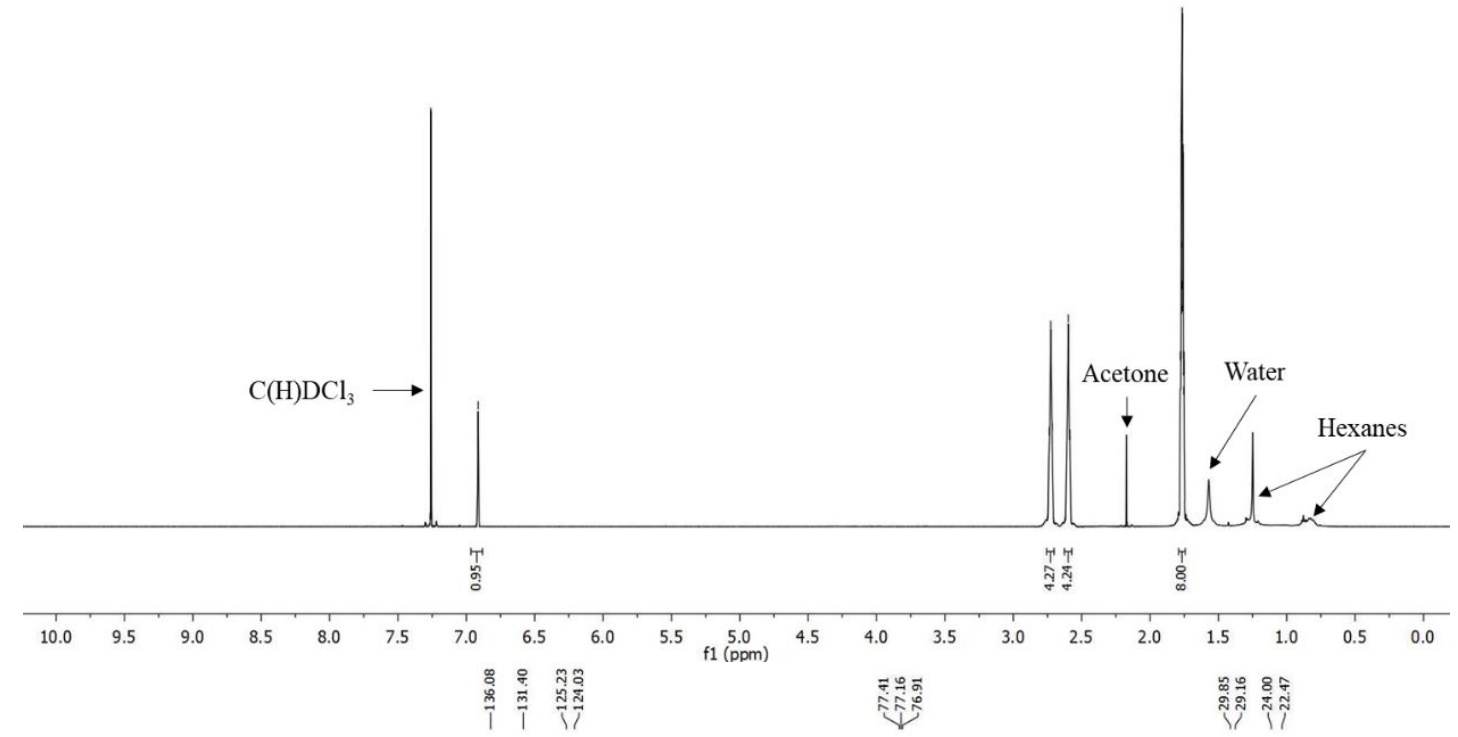

${ }^{13} \mathrm{C}$ NMR $\left(126 \mathrm{MHz}, \mathrm{CDCl}_{3}\right)$
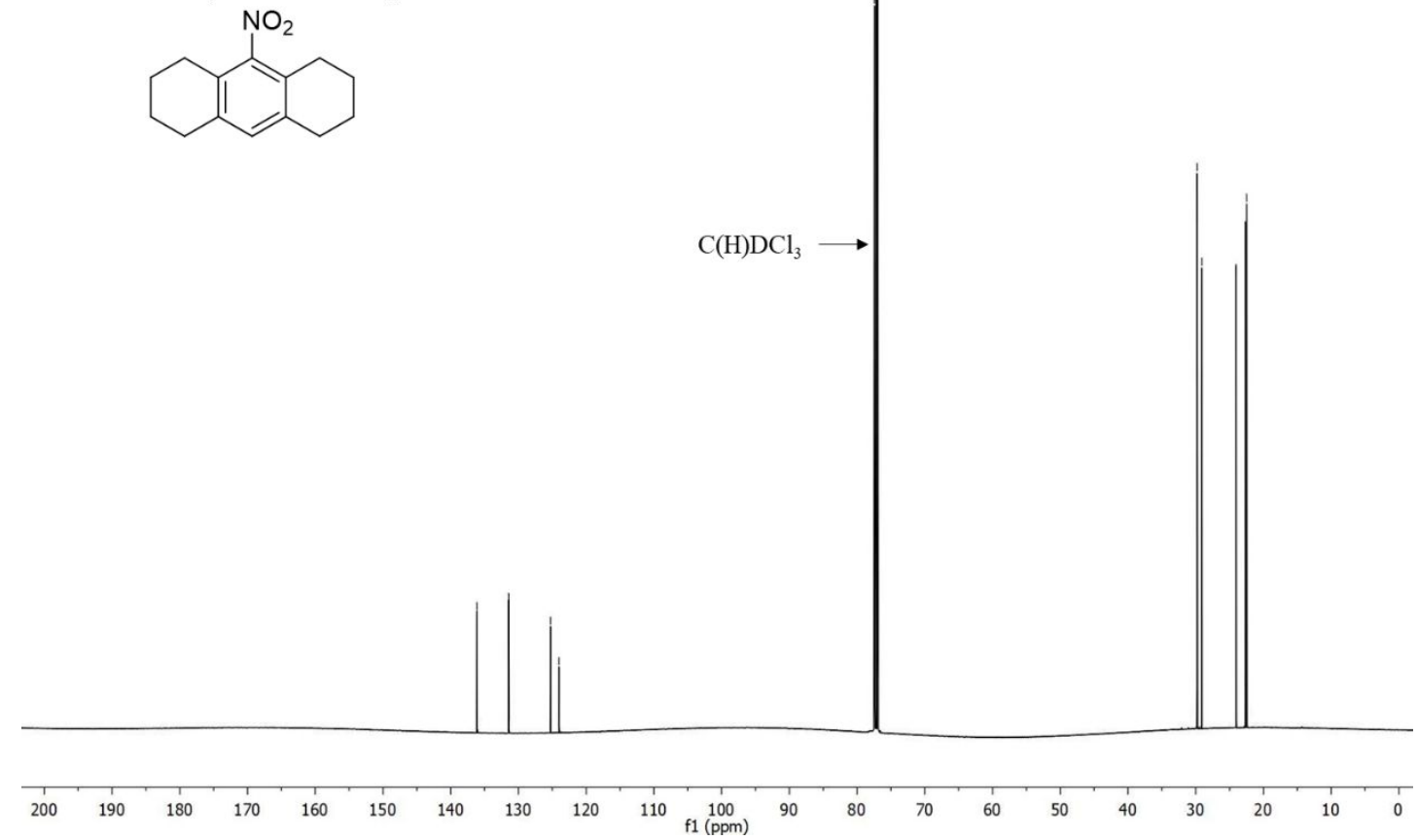

Figure S7. ${ }^{1} \mathrm{H}$ and ${ }^{13} \mathrm{C}$ NMR spectra of 9-nitro-1,2,3,4,5,6,7,8-octahydroanthracene $\left(\mathbf{5 N O}_{\mathbf{2}}\right)$ in $\mathrm{CDCl}_{3}$. 


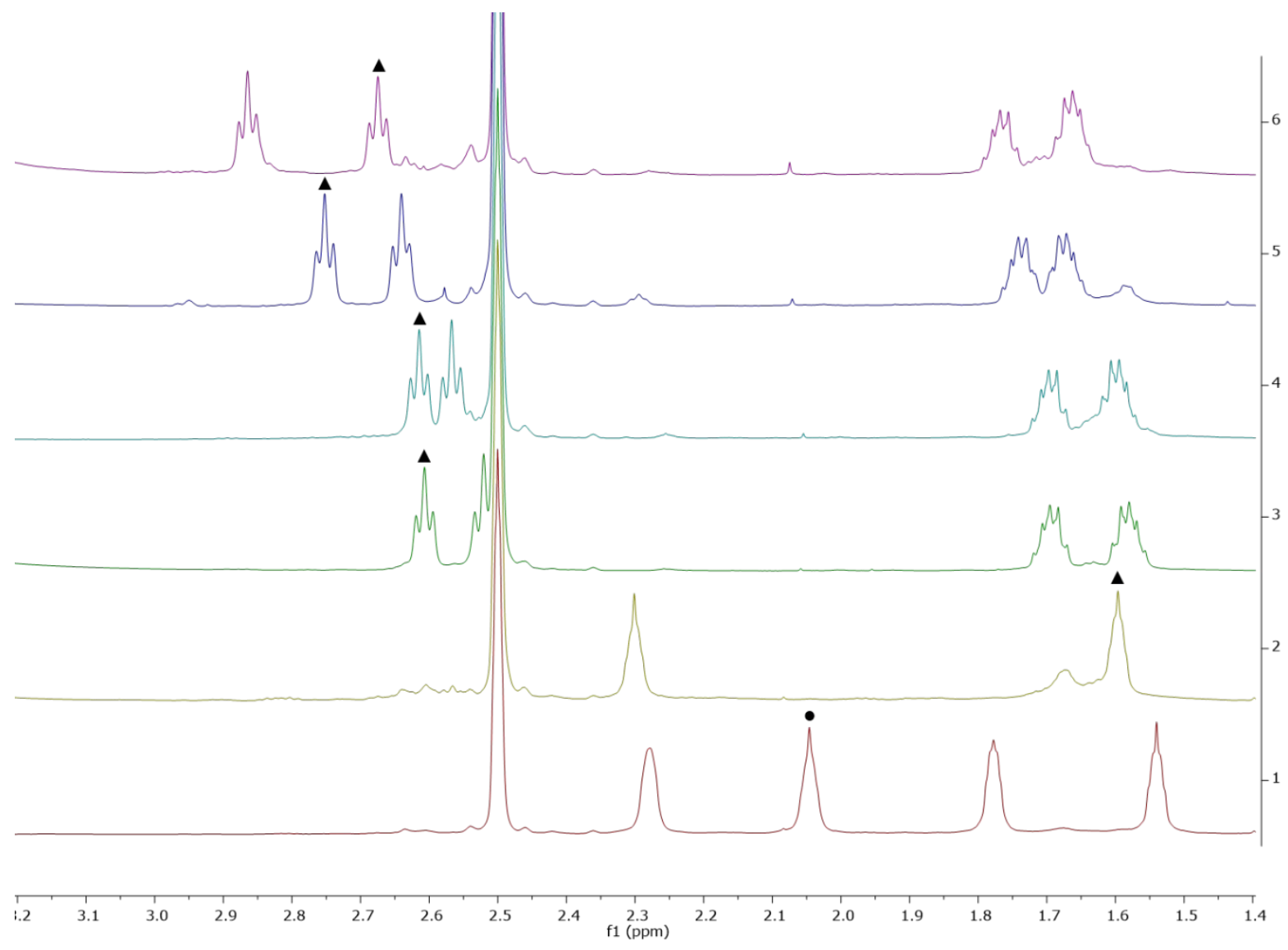

Figure S8. ${ }^{1} \mathrm{H}$ NMR spectra from experiment involving reaction of $5 \mathrm{mM}$ enediyne 3 plus 50 $\mathrm{mM}$ pivalic acid in DMSO- $d_{6}$ at $75^{\circ} \mathrm{C}$ at $0 \mathrm{~h} \mathrm{(1)} \mathrm{and} \mathrm{at} 20 \mathrm{~h}(2)$ with nucleophiles (100 equiv, $500 \mathrm{mM})$ at $75^{\circ} \mathrm{C}$ for $20 \mathrm{~h}\left(3 . \mathrm{I}^{-}, 4 . \mathrm{Br}^{-}, 5 . \mathrm{CN}^{-}, 6 . \mathrm{SCN}^{-}\right)$. Disappearance of 3 was monitored by integration of the propargyl $\mathrm{CH}_{2}$ resonance $(\delta 2.05 \mathrm{ppm}, 4 \mathrm{H})$, denoted by $\bullet$, and the formation of products was monitored by the integration of homobenzylic $\mathrm{CH}_{2}(\delta 1.60 \mathrm{ppm}, 8 \mathrm{H})$ of $\mathbf{5 H}$, benzylic $\mathrm{CH}_{2}$ ortho- $(\delta 2.61 \mathrm{ppm}, 4 \mathrm{H})$ of $\mathbf{5 I}$, benzylic $\mathrm{CH}_{2}$ ortho- $(\delta 2.62 \mathrm{ppm}, 4 \mathrm{H})$ of $\mathbf{5 B r}$, benzylic $\mathrm{CH}_{2}$ ortho- $(\delta 2.75 \mathrm{ppm}, 4 \mathrm{H})$ of $\mathbf{5 C N}$, or benzylic $\mathrm{CH}_{2}$ para- $(\delta 2.68 \mathrm{ppm}, 4 \mathrm{H})$ of $\mathbf{5 S C N}$, denoted by $\boldsymbol{\Delta}$, relative to $1,3,5$-trichlorobenzene $(\delta 7.66 \mathrm{ppm})$. 


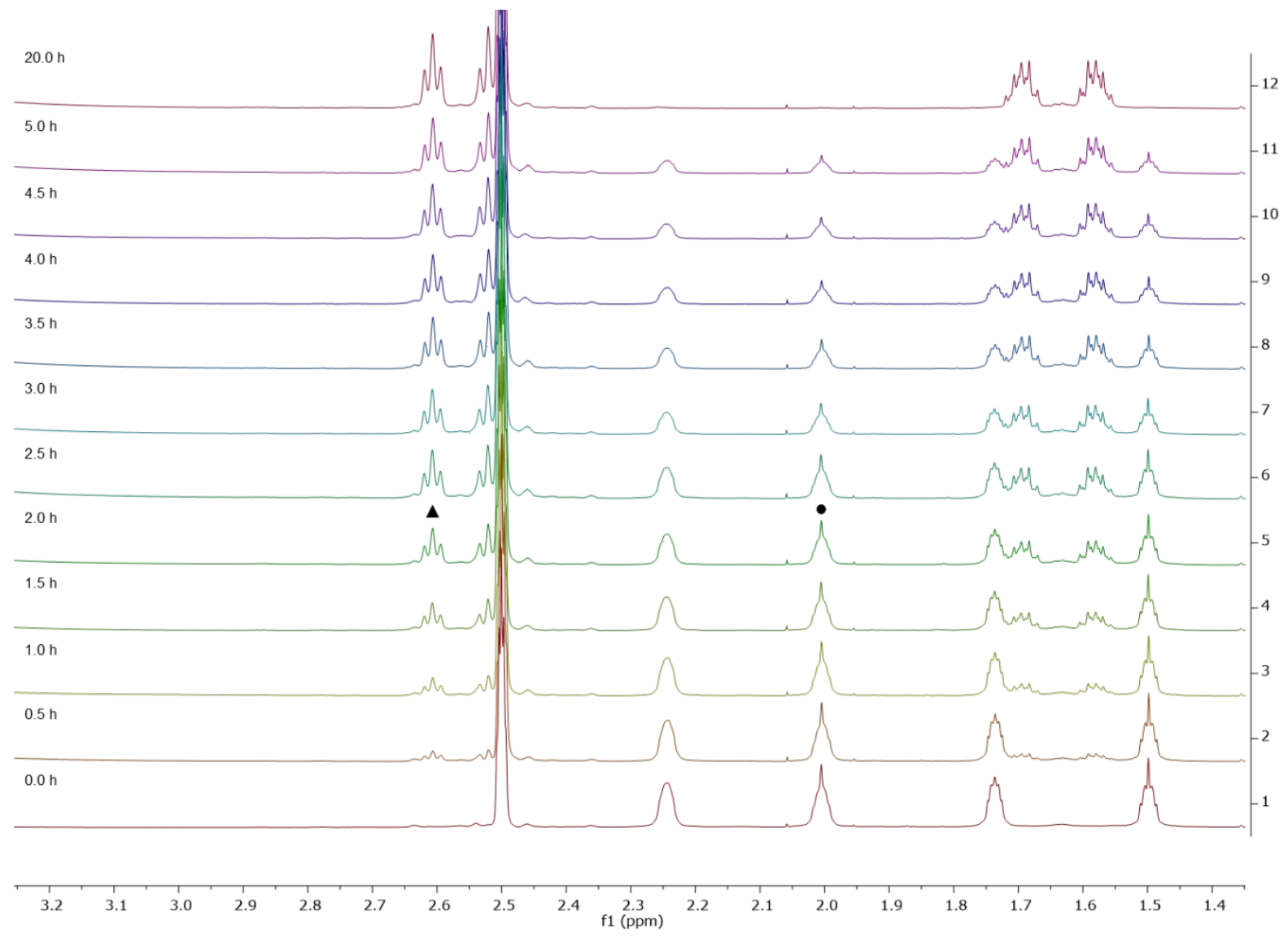

Figure S9. Typical ${ }^{1} \mathrm{H}$ NMR spectra from an experiment involving 3 (5 mM), LiI (500 mM), and pivalic acid $(50 \mathrm{mM})$ in DMSO- $d_{6}$ at $75^{\circ} \mathrm{C}$. Disappearance of 3 was monitored by integration of the propargyl $\mathrm{CH}_{2}$ resonance $(\delta 2.05 \mathrm{ppm}, 4 \mathrm{H})$, denoted by $\boldsymbol{\Lambda}$, and formation of product was monitored by the integration of benzylic $\mathrm{CH}_{2}$ ortho- $(\delta 2.61 \mathrm{ppm}, 4 \mathrm{H})$ of $\mathbf{5 I}$, denoted by $\boldsymbol{\bullet}$, relative to $1,3,5$-trichlorobenzene $(\delta 7.66 \mathrm{ppm})$. 


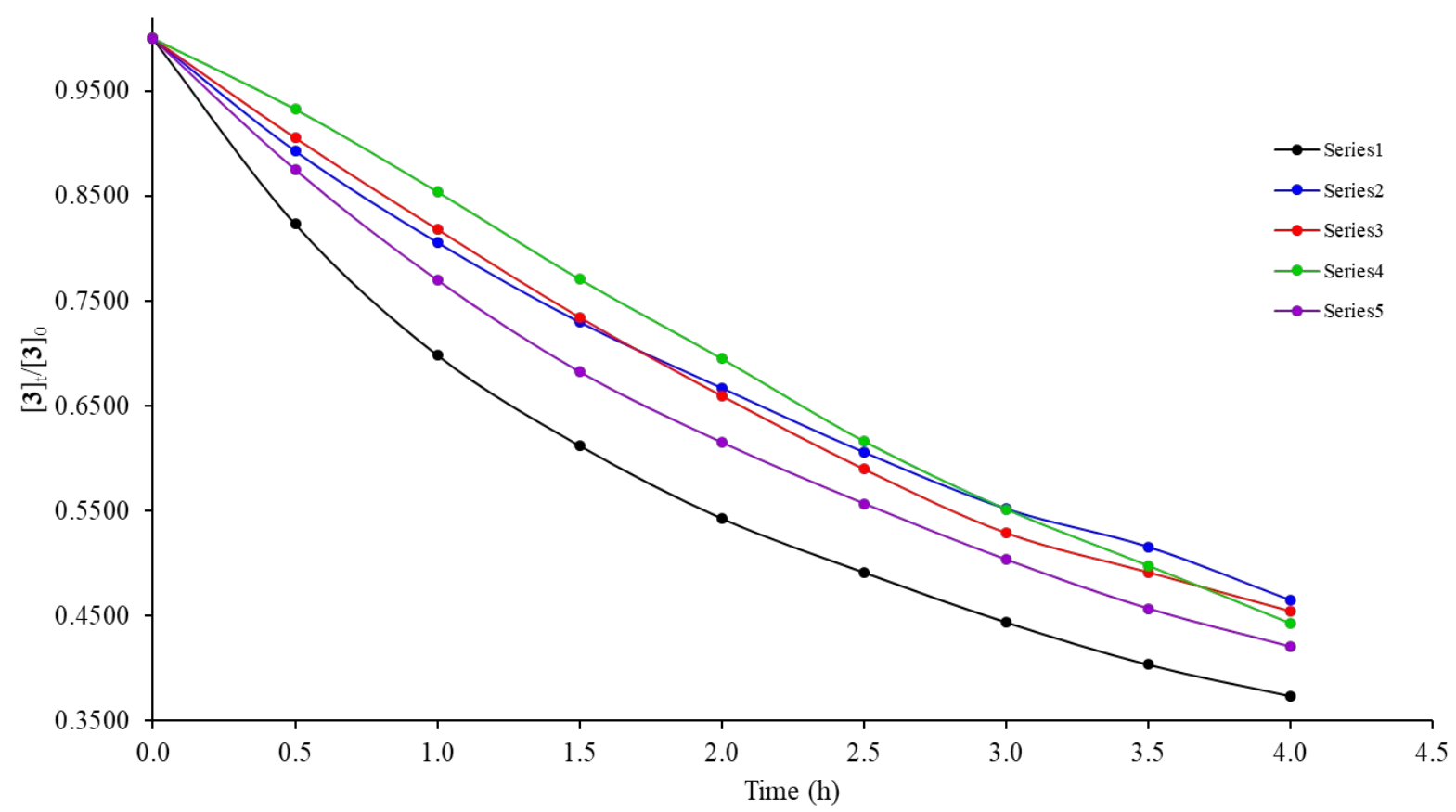

Figure S10. Plot of $[3]_{\mathrm{t}} /[3]_{0}$ versus time for experiments involving enediyne $3(5 \mathrm{mM})$, nucleophile $\mathrm{X}^{-}(500 \mathrm{mM})$, and pivalic acid $(50 \mathrm{mM})$ in DMSO- $d_{6}$ at $75^{\circ} \mathrm{C}$. Series 1 . With no nucleophile, Series 2. With $\mathrm{X}^{-}=\mathrm{I}^{-}$, Series 3. With $\mathrm{X}^{-}=\mathrm{Br}^{-}$, Series 4. With $\mathrm{X}^{-}=\mathrm{CN}^{-}$, Series 5 . With $\mathrm{X}^{-}=\mathrm{SCN}^{-}$. 


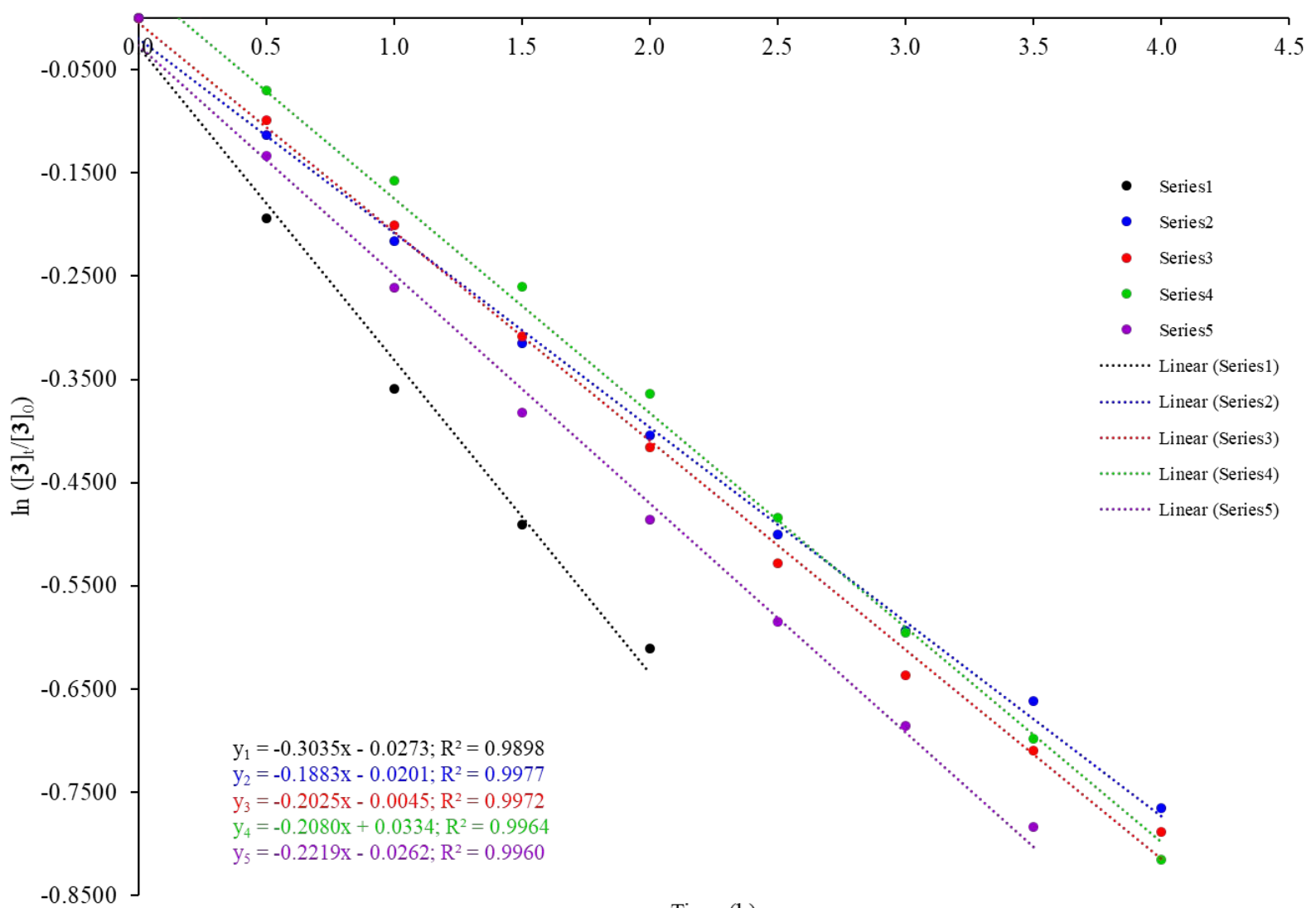

Time (h)

Figure S11. Plot of $\ln [3]_{\mathrm{t}} /[3]_{0}$ versus time for experiments involving enediyne $3(5 \mathrm{mM})$, nucleophile $\mathrm{X}^{-}(500 \mathrm{mM})$, and pivalic acid $(50 \mathrm{mM})$ in DMSO $-d_{6}$ at $75^{\circ} \mathrm{C}$. Series 1 . With no nucleophile, Series 2. With $\mathrm{X}^{-}=\mathrm{I}^{-}$, Series 3. With $\mathrm{X}^{-}=\mathrm{Br}^{-}$, Series 4. With $\mathrm{X}^{-}=\mathrm{CN}^{-}$, Series 5. With $\mathrm{X}^{-}=\mathrm{SCN}^{-}$. Only those points which gives best linear fit are considered. 
Table S1. First-order rate constants and free energies of activation for the disappearance of enediynes 1-3 (5 mM) in the presence of LiX and pivalic acid $(7.5 \mathrm{mM})$ in DMSO- $d_{6}$.

\begin{tabular}{|c|c|c|c|c|c|}
\hline Enediyne & $\mathrm{X}^{-}$ & $T(\mathrm{~K})$ & {$\left[\mathrm{X}^{-}\right]$} & $10^{5} k\left(\mathrm{~s}^{-1}\right)$ & $\Delta G^{\ddagger}(\mathrm{kcal} / \mathrm{mol})$ \\
\hline \multirow{5}{*}{1} & \multirow{5}{*}{$\mathrm{I}^{-}$} & \multirow{2}{*}{318} & 250 & 2.95 & 25.2 \\
\hline & & & 500 & 3.03 & 25.2 \\
\hline & & \multirow{3}{*}{328} & 250 & 9.58 & 25.3 \\
\hline & & & 500 & 9.60 & 25.3 \\
\hline & & & & Mean: & $25.3 \pm 0.0$ \\
\hline \multirow{11}{*}{2} & \multirow{2}{*}{$1,4-\mathrm{CHD}^{\mathrm{a}}$} & \multirow{2}{*}{357} & 250 & $0.448\left(0.494^{b}\right)$ & $29.8\left(29.7^{b}\right)$ \\
\hline & & & 500 & $0.775\left(0.802^{b}\right)$ & $29.4\left(29.4^{b}\right)$ \\
\hline & \multirow{2}{*}{$\mathrm{Cl}^{-}$} & \multirow{2}{*}{358} & 250 & 0.342 & 30.0 \\
\hline & & & 500 & 0.397 & 29.9 \\
\hline & \multirow{2}{*}{$\mathrm{Br}^{-}$} & \multirow{2}{*}{358} & 250 & 1.27 & 29.1 \\
\hline & & & 500 & 1.91 & 28.8 \\
\hline & \multirow{5}{*}{$\mathrm{I}^{-}$} & \multirow{2}{*}{358} & 250 & 2.43 & 28.6 \\
\hline & & & 500 & 2.93 & 28.5 \\
\hline & & \multirow{3}{*}{368} & 250 & 7.08 & 28.7 \\
\hline & & & 500 & 7.22 & 28.7 \\
\hline & & & & Mean: & $28.6 \pm 0.1$ \\
\hline \multirow{5}{*}{3} & \multirow{5}{*}{$\mathrm{I}^{-}$} & \multirow{2}{*}{338} & 250 & 1.71 & 27.2 \\
\hline & & & 500 & 1.94 & 27.2 \\
\hline & & \multirow{3}{*}{348} & 250 & 5.21 & 27.3 \\
\hline & & & 500 & 5.23 & 27.3 \\
\hline & & & & Mean: & $27.2 \pm 0.1$ \\
\hline
\end{tabular}

${ }^{\mathrm{a}}$ Disappearance monitored in $t$-BuOH. ${ }^{3},{ }^{\mathrm{b}}$ Derived from previously reported half-lives. ${ }^{3}$ 
Table S2. Distances $(\AA)$, bond angles $\left({ }^{\circ}\right)$, and total strain energies $(\mathrm{kcal} / \mathrm{mol})$ in MM2 energyminimized structures of enediynes 1-3.

\begin{tabular}{|c|c|c|c|}
\hline \multirow{2}{*}{ Measurement } & \multicolumn{3}{|c|}{ Enediyne } \\
\hline & 1 & 2 & 3 \\
\hline$C(3)-C(4)$ & 1.34 & 1.42 & 1.34 \\
\hline $\mathrm{C}(2)-\mathrm{C}(5)$ & 2.52 & 2.63 & 2.52 \\
\hline$C(1)-C(6)$ & 3.26 & 3.46 & 3.32 \\
\hline$C(10)-C(7)$ & 3.68 & 3.77 & 3.72 \\
\hline$C(5)-C(4)-C(3)$ & 116.6 & 117.3 & 116.4 \\
\hline$C(2)-C(3)-C(4)$ & 116.6 & 117.6 & 116.7 \\
\hline$C(6)-C(5)-C(4)$ & 171.3 & 172.0 & 172.6 \\
\hline$C(1)-C(2)-C(3)$ & 171.2 & 172.4 & 172.8 \\
\hline$C(7)-C(6)-C(5)$ & 170.1 & 165.1 & 168.3 \\
\hline$C(10)-C(1)-C(2)$ & 170.0 & 165.6 & 168.6 \\
\hline$C(8)-C(7)-C(6)$ & 112.8 & 109.3 & 110.8 \\
\hline $\mathrm{C}(9)-\mathrm{C}(10)-\mathrm{C}(1)$ & 112.8 & 109.3 & 110.9 \\
\hline $\mathrm{C}(9)-\mathrm{C}(8)-\mathrm{C}(7)$ & 116.2 & 113.5 & 114.8 \\
\hline$C(8)-C(9)-C(10)$ & 116.2 & 114.4 & 114.8 \\
\hline $\mathrm{C}(2)-\mathrm{C}(3)-\mathrm{C}(4)-\mathrm{C}(5)$ & -1.1 & 0.9 & -1.3 \\
\hline$C(7)-C(6)-C(5)-C(4)$ & -3.2 & 5.8 & -9.8 \\
\hline$C(10)-C(1)-C(2)-C(3)$ & -3.2 & -5.4 & 8.1 \\
\hline $\mathrm{C}(8)-\mathrm{C}(7)-\mathrm{C}(6)-\mathrm{C}(5)$ & 32.7 & -2.4 & 10.1 \\
\hline $\mathrm{C}(9)-\mathrm{C}(10)-\mathrm{C}(1)-\mathrm{C}(2)$ & 32.8 & -5.8 & 15.9 \\
\hline $\mathrm{C}(9)-\mathrm{C}(8)-\mathrm{C}(7)-\mathrm{C}(6)$ & -71.7 & -72.8 & -73.1 \\
\hline$C(8)-C(9)-C(10)-C(1)$ & -72.0 & -69.0 & -71.0 \\
\hline $\mathrm{C}(7)-\mathrm{C}(8)-\mathrm{C}(9)-\mathrm{C}(10)$ & 109.3 & 128.5 & 118.0 \\
\hline Total Strain Energy & 11.66 & 9.564 & 14.77 \\
\hline
\end{tabular}

